\title{
Seasonal carbon cycling in a Greenlandic fjord: an integrated pelagic and benthic study
}

\author{
Heidi L. Sørensen ${ }^{1,2, *}$, Lorenz Meire ${ }^{2,3,4}$, Thomas Juul-Pedersen ${ }^{2}$, Henko C. de Stigter ${ }^{5}$, \\ Filip J. R. Meysman ${ }^{3,6}$, Søren Rysgaard ${ }^{2,7,8,9}$, Bo Thamdrup ${ }^{1}$, Ronnie N. Glud ${ }^{1,2,9,10}$ \\ ${ }^{1}$ Nordic Centre for Earth Evolution (NordCEE), Dept of Biology, University of Southern Denmark (SDU), 5230 Odense, Denmark \\ ${ }^{2}$ Greenland Climate Research Centre (GCRC), Greenland Institute of Natural Resources, 3900 Nuuk, Greenland \\ ${ }^{3}$ Royal Netherlands Institute of Sea Research (NIOZ), Department of Ecosystem Studies, 4401 NT, Yerseke, The Netherlands \\ ${ }^{4}$ University of Ghent (UGent), Marine Biology Laboratory, 9000 Gent, Belgium \\ ${ }^{5}$ Royal Netherlands Institute of Sea Research (NIOZ), Dept of Geology and Chemical Oceanography, 1790 AB Den Burg - Texel, \\ The Netherlands \\ ${ }^{6}$ Dept of Analytical, Environmental and Geochemistry (AMGC), Vrije University of Brussels (VUB), 1050 Brussels, Belgium \\ ${ }^{7}$ Centre for Earth Observation Science, Dept of Environment and Geography, University of Manitoba, Winnipeg, \\ MB R3T 2N2, Canada \\ ${ }^{8}$ Dept of Geological Sciences, University of Manitoba, Winnipeg, MB R3T 2N2, Canada \\ ${ }^{9}$ Arctic Research Centre, Aarhus University, 8000 Aarhus, Denmark \\ ${ }^{10}$ Scottish Association for Marine Science, Scottish Marine Institute, Oban PA37 1QA, UK
}

\begin{abstract}
Climate change is expected to have a pronounced effect on biogeochemical cycling in Arctic fjords, but current insight on the biogeochemical functioning of these systems is limited. Here, we present seasonal data on primary production, export of particulate organic carbon (POC), and the coupling to benthic biogeochemistry in Kobbefjord (SW Greenland). Primary production and associated POC export from the photic zone showed marked seasonality, with annual integrated values of 7.2 and $19.9 \mathrm{~mol} \mathrm{C}$ $\mathrm{m}^{-2} \mathrm{yr}^{-1}$, respectively. This discrepancy, the isotopic signature, and $\mathrm{C}: \mathrm{N}$ ratio of the sedimentating material suggested substantial import of marine POC from outside the fjord. At least $52 \%$ of the POC export reached the sediment, but the seasonality in pelagic productivity was not reflected in the sediment biogeochemistry, showing only moderate variation. Benthic mineralization and burial of organic carbon amounted to 3.2 and $5.3 \mathrm{~mol} \mathrm{C} \mathrm{m}^{-2} \mathrm{yr}^{-1}$, respectively. Sulfate reduction was the most prominent mineralization pathway, accounting for $69 \%$ of the benthic mineralization, while denitrification accounted for $2 \%$. Overall, the carbon mineralization and burial in Kobbefjord were significantly higher than previously observed in other more northerly Arctic fjords. Data compilation from Arctic fjords suggests proportional increases in surface production, POC export, benthic mineralization and burial of organic material with increasing duration of the ice-free period. Thus, the projected decline in ice coverage in higher Arctic Greenlandic fjords will, as a first approximation, entail proportional increases in productivity, mineralization, and burial of organic carbon in the fjords, which will thus become similar to present-day southerly systems.
\end{abstract}

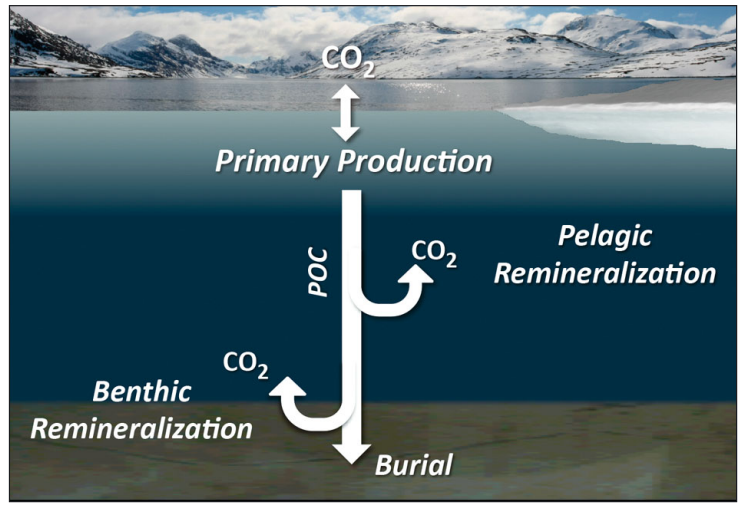

Schematic of carbon cycling in Kobbefjord, Greenland.

Photo: Lorenz Meire; Illustration: Heidi L. Sørensen

KEY WORDS: Arctic - Climate changes · Primary production · POC export · Benthic biogeochemistry · Denitrification · Anammox · Sulfate reduction

\section{INTRODUCTION}

The Arctic region is currently undergoing dramatic climatic changes (Vaughan et al. 2013), and coastal areas in Greenland are experiencing increasing temperatures, enhanced precipitation, and intensified meltwater runoff (Bindoff et al. 
2007, Stendel et al. 2007, Bamber et al. 2012). The result is an extended sea-ice-free period and a modified hydrographic structure and circulation in many fjords (Bindoff et al. 2007). This is likely to affect the light and nutrient availability in the surface waters of the fjords, which as a result will affect primary production, cycling of organic material, and, ultimately, the foodweb structure in Greenlandic fjords (Rysgaard \& Glud 2007).

The Greenlandic coastline stretches across $23^{\circ}$ of latitude from the low- to the high-Arctic, representing an extensive climate gradient. It is anticipated that ongoing climate changes will cause a shift in coastal ecosystems along this north-south climate gradient, so that future conditions at northern sites will resemble the current conditions at the more southern sites (Rysgaard et al. 2003). Therefore, a more detailed understanding of biogeochemical cycling in low-Arctic fjords may help in projecting how high-Arctic fjords will transform with ongoing climate changes. However, comprehensive studies of carbon cycling in Greenlandic fjords are scarce, and particularly the seasonal variation in biogeochemical cycles and their annual integrals remain to be quantified (Rysgaard \& Glud 2007).

The present study investigates the seasonal pelagic primary production, particulate organic carbon (POC) export, and sedimentary carbon cycling in the low-Arctic Kobbefjord (SW Greenland). The area is studied within an ongoing monitoring program, Marine Basic Nuuk, which is part of the Greenland Ecosystem Monitoring Program (GEM) that follows key meteorological, physical, chemical, and biological parameters in the region (www.g-e-m.dk). Here, we studied the biogeochemical cycling in Kobbefjord and established an annual integrated carbon budget. The results are compared to other Arctic coastal systems and discussed within the context of projected climate changes in the Arctic region.

\section{MATERIALS AND METHODS}

\section{Study site and sampling}

Kobbefjord (Kangerluarsunnguaq) covers an area of $25 \mathrm{~km}^{2}$ and is situated near the town of Nuuk, SW Greenland (Fig. 1A,B). The fjord consists of several deeper basins separated by sills, and has an average water depth of $51 \mathrm{~m}$. The entrance to the fjord has a distinctive sill at $30 \mathrm{~m}$ depth, while the maximum water depth is $140 \mathrm{~m}$ (Fig. 1C, Mikkelsen et al. 2008). The total catchment area is small $\left(58 \mathrm{~km}^{2}\right)$ and re- ceives freshwater run-off from 4 minor rivers, partly fed by melting 'dead-ice,' i.e. the remnants of old glaciers. The majority of the freshwater at the surface layer of Kobbefjord originates from the adjacent Godthåbsfjord, which is fed by 6 major glaciers (J. Mortensen et al. unpubl. results). Our study site was located in the central basin of Kobbefjord with a water depth of $110 \mathrm{~m}$ (Fig. 1C). The site was visited monthly between May 2011 and May 2012 for benthic (sediment cores) and pelagic water sampling. Additionally, 3 sediment cores were collected in February 2013 for quantification of sediment burial rates based on ${ }^{210} \mathrm{~Pb}$ measurements. The pelagic program included measurements of gross primary production, POC export, and hydrographic parameters (water column salinity, temperature, density), while benthic investigations were based on the recovery of 9 to 22 sediment cores each month for quantification of sediment characteristics and benthic biogeochemistry.

\section{Pelagic sampling}

At every sampling session, depth profiles of conductivity, salinity, temperature, density, oxygen $\left(\mathrm{O}_{2}\right)$, photosynthetically active radiation, and fluorescence were obtained by a Seabird 19 plus CTD instrument (Seabird Electronics). Temperature and salinity data were used to calculate the stratification parameter $\phi$ $\left(\mathrm{J} \mathrm{m}^{-3}\right)$, which is defined as the amount of energy required to fully mix the water column through vertical mixing (Simpson 1981):

with

$$
\begin{gathered}
\phi=\frac{1}{h} \int_{-h}^{0}\left(\rho_{\mathrm{av}}-\rho_{\mathrm{w}}\right) g z \mathrm{~d} z \\
\rho_{\mathrm{av}}=\frac{1}{h} \int_{-h}^{0} \rho_{\mathrm{w}} z \mathrm{~d} z
\end{gathered}
$$

where $h$ is the total height of the water column (m), $z$ is depth $(\mathrm{m}), g$ is gravitational acceleration $\left(\mathrm{m} \mathrm{s}^{-2}\right), \rho_{w}$ is water density $\left(\mathrm{kg} \mathrm{m}^{-3}\right)$, and $\rho_{\mathrm{av}}$ is the average water column density $\left(\mathrm{kg} \mathrm{m}^{-3}\right)$.

Water samples from 5, 10, 20, 30, 40, and $105 \mathrm{~m}$ were retrieved using a $10 \mathrm{l}$ Niskin bottle (KC Research Equipment). The $\mathrm{O}_{2}$ concentration was measured in recovered surface water $(5 \mathrm{~m})$ and bottom water $(105 \mathrm{~m})$ using Winkler titrations. Water samples from the upper 5 depths $(5,10,20,30,40 \mathrm{~m})$ were used for in situ bottle incubations for primary production, while bottom water $(105 \mathrm{~m})$ was used for performing whole core sediment incubations. Primary production was measured using a modified version of the original ${ }^{14} \mathrm{C}$-incubation method (Steeman Nielsen 1952). Water was transferred to $120 \mathrm{ml}$ glass 

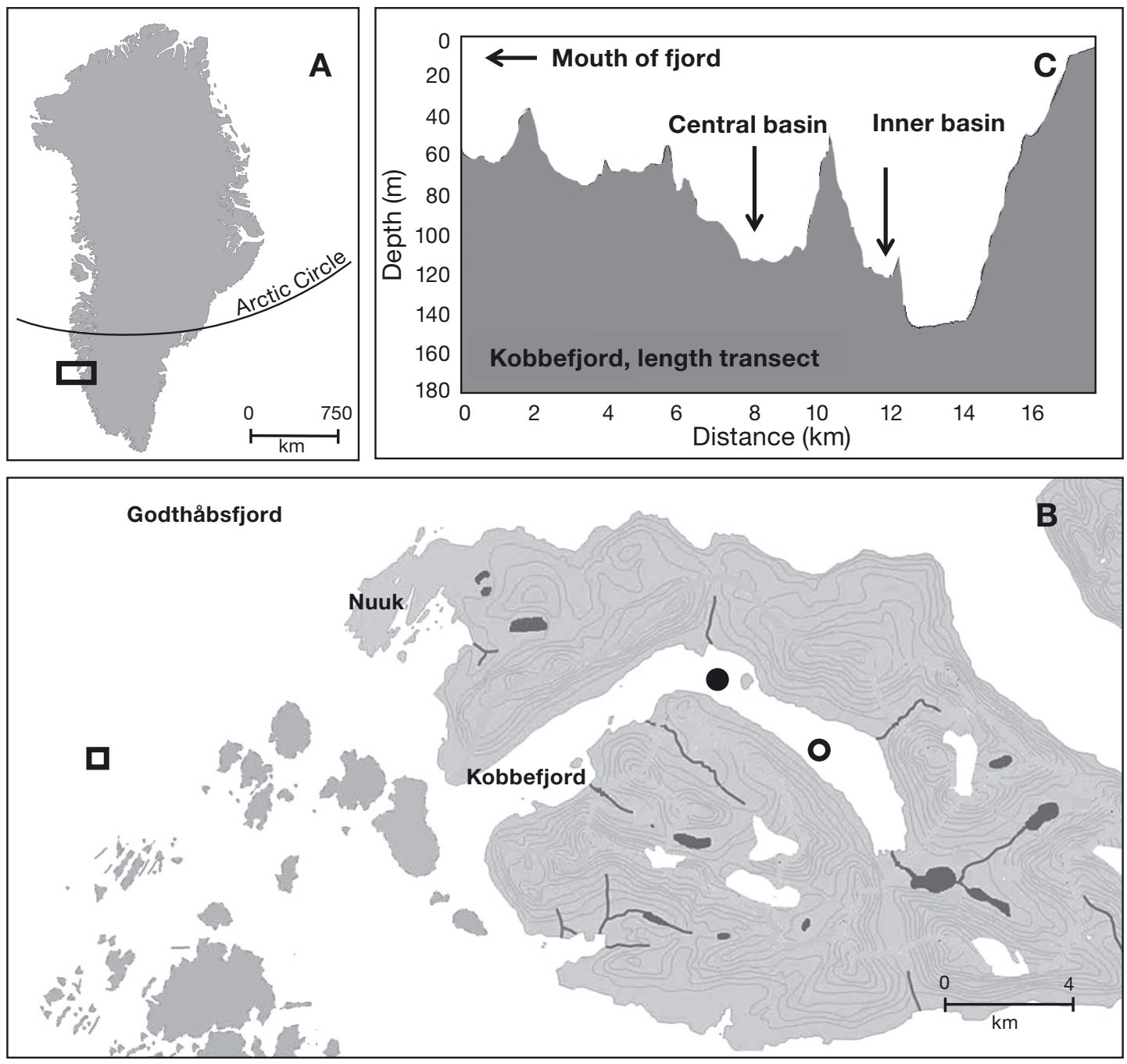

Fig. 1. (A, B) Location of Kobbefjord on the SW coast of Greenland in close vicinity to Nuuk and Godthåbsfjord. The study site $\left(64^{\circ} 10.479^{\prime} \mathrm{N}, 51^{\circ} 31.269^{\prime} \mathrm{W}\right)$ is marked by a filled circle in (B), the open square marks the location of the Marine Basic Nuuk main monitoring station and the open circle marks the location of the Marine Basic Nuuk sediment monitoring station (modified from Jensen \& Rasch 2009). (C) Bathymetry along the central length transect in Kobbefjord, with arrows indicating the position of the central basin (our study site) and the inner basin

bottles (Hirshmann ${ }^{\circledR}$ Laboratory Equipment), and for each depth, 2 bottles were used as light duplicates and 1 was used for dark incubation. All bottles were spiked with $200 \mu \mathrm{l} \mathrm{NaH}{ }^{14} \mathrm{CO}_{3}\left(20 \mu \mathrm{Ci} \mathrm{ml}^{-1}\right)$ and incubated at the respective sampling depths for a minimum of $2 \mathrm{~h}$ using a free-drifting buoy. At the end of the incubations, the bottles were placed in a dark and thermally insulated box, until they were processed in the laboratory (typically within $3 \mathrm{~h}$ ). Back in the laboratory, the incubated water was filtered on GF/C filters (Whatman), and filters were transferred to $20 \mathrm{ml}$ scintillation vials, where $100 \mu \mathrm{HCl}(0.1 \mathrm{M})$ was added to remove excess $\mathrm{NaH}^{14} \mathrm{CO}_{3}$. After $24 \mathrm{~h}$ in the fume hood, scintillation cocktail (Ultima Gold, Perkin Elmer) was added to the samples and samples were counted (Liquid Scintillation Analyzer, TriCarb 2800TR, PerkinElmer; Rysgaard et al. 2012). Primary production was calculated accounting for the ${ }^{14} \mathrm{C}$ incorporation during photosynthesis (disintegrations per minute, dpm $_{\text {Light }}$, the in situ concentrations of dissolved inorganic carbon $\left(\mathrm{C}_{\text {DIC }}\right)$, isotope discrimination (1.05), the correction for simultaneous respiration (1.06), dark fixation of ${ }^{14} \mathrm{C}\left(\mathrm{dpm}_{\text {Dark }}\right)$, the specific activity of the added $\mathrm{NaH}^{14} \mathrm{CO}_{3}\left(\mathrm{Act}_{\mathrm{C} 14}\right)$, and the counting efficiency of the instrument according to formula below (where $t$ is time in hours): 


Primary Production $=$
$\frac{\mathrm{dpm}_{\text {Light }} \times \mathrm{C}_{\text {DIC }} \times 1.05 \times 1.06}{\mathrm{Act}_{\mathrm{C} 14} \times t}-\frac{\mathrm{dpm}_{\text {Dark }} \times \mathrm{C}_{\text {DIC }} \times 1.05 \times 1.06}{\mathrm{Act}_{\mathrm{C} 14} \times t}$

To calculate daily productivity, the primary production rates obtained from incubations were multiplied by the ratio of the average solar irradiance over the incubation period versus the average daily irradiance (values provided by ASIAQ; www. asiaq.gl, see location of 'Climate station' in Jensen \& Rasch 2012). Depth-integrated values of primary production were calculated over the entire photic zone using trapezoid integration, assuming that the primary production rate at $5 \mathrm{~m}$ represents that in the upper 0 to $7.5 \mathrm{~m}$. Below $40 \mathrm{~m}$, the primary production rates were assumed to decrease linearly to 0 at the depth where light availability was less than $1 \%$ of the surface intensity (defined as the end of the photic zone).

Export of POC was determined from a free-drifting sediment trap consisting of 2 acrylic cylinders $(7.2 \mathrm{~cm}$ i.d., $50 \mathrm{~cm}$ in height) deployed for 2 to $4 \mathrm{~h}$ at 60 to $65 \mathrm{~m}$ water depth. Prior to deployments, the cylinders were filled with 21 of filtered sea water with additional salt added (excess salinity of $5 \mathrm{psu}$ ). At the end of the incubation, the cylinders were recovered, sealed, and placed in darkness until further processing in the laboratory. Water from 2 traps was filtered onto pre-combusted GF/C filters (Whatman). Larger fresh zooplankton was carefully removed using tweezers. In order to discriminate between the organic and inorganic carbon, a part of each filter was acidified to dissolve calcium carbonates, leaving only the organic fraction (Juul-Pedersen et al. 2006). The acidified and non-acidified samples were placed in tin (Sn) capsules for measurements of total carbon, POC, C:N ratio, and $\delta^{13} \mathrm{C}$ using mass spectrometry (Isotope Ratio Mass Spectrometer Hydra 20-20, SerCon; Autosampler: SerCon; Separation unit: Gas Solid Liquid Sample Prep Unit, ANCA GSL, SerCon).

\section{Benthic sampling}

Sediment cores were retrieved in Plexiglas ${ }^{\mathrm{TM}}$ core liners $(5.3 \mathrm{~cm}$ i.d., length 30 to $50 \mathrm{~cm})$ using a Kajak sampler (KC Research Equipment). In the laboratory, 6 cores were submerged in an aquarium containing sampled bottom water, which was kept at in situ temperature and $\mathrm{O}_{2}$ saturation. Rotating magnets were fixed inside the core liners at $5 \mathrm{~cm}$ distance from the sediment surface to ensure efficient mixing of the overlying water column (Ras- mussen \& Jørgensen 1992). On the following day, $\mathrm{O}_{2}$ microprofiles were measured using custommade Clark-type $\mathrm{O}_{2}$ microelectrodes equipped with a guard cathode (Revsbech 1989). A total of 6 to 12 microprofiles were measured in 3 different sediment cores. The diffusive oxygen uptake (DOU) was calculated from the $\mathrm{O}_{2}$ concentration gradient in the diffusive boundary layer above the sediment-water interface using Fick's first law, calculating the molecular diffusion coefficient for $\mathrm{O}_{2}$ as a function of temperature and salinity (Li \& Gregory 1974, Rasmussen \& Jørgensen 1992). The depthspecific $\mathrm{O}_{2}$ consumption rates within the sediment were estimated from the measured microprofiles using the software package 'PROFILE' (Berg et al. 1998). A series of least-square fits is produced by the software package, and the simplest production/ consumption profile that fits the measured concentration profile, given a user-defined number of production zones, is generated through statistical Ftesting.

On the following day, the cores were capped with Plexiglas lids and incubated for a period of 8 to $10 \mathrm{~h}$. Each transparent lid was equipped with a patch of $\mathrm{O}_{2}$-quenchable luminophores. The $\mathrm{O}_{2}$ concentration in the water overlying the sediment was measured hourly using a fiber-optic oxygen transmitter unit (FIBOX - Fibox 3, PreSens, software: OxyView). The sensor patches were calibrated using $100 \%$ airsaturated bottom water and bottom water spiked with sodium dithionite $\left(\mathrm{NaHSO}_{3}\right)$ as an anoxic end member. Samples for DIC were recovered at the start and end of the incubation. The water was transferred to $12.6 \mathrm{ml}$ exetainers (Labco) using a glass syringe equipped with a gastight tube and spiked with $100 \mu \mathrm{l}$ saturated $\mathrm{HgCl}_{2}$. The DIC was analyzed using either a coulometer $\left(\mathrm{CM} 5012 \mathrm{CO}_{2}\right.$ Coulometer, UIC Coulometrics) or a DIC analyzer (Apollo SciTech, Model AS-C3, USA). The DIC and $\mathrm{O}_{2}$ exchange rates across the sediment-water interface were calculated from the measured concentration change in the overlying water of the incubations accounting for the enclosed volume of water as described by Glud (2008).

\section{Denitrification and anammox}

Denitrification rates were determined via ${ }^{15} \mathrm{NO}_{3}{ }^{-}$ amendments to the overlying water of 3 intact sediment cores using the IPT method (Nielsen 1992), modified to account for the contribution from anammox (Risgaard-Petersen et al. 2003, Rysgaard 
et al. 2004). The incubations were ended by gently slurrying the core and transferring slurry to $12.6 \mathrm{ml}$ exetainers (Labco) spiked with $200 \mu \mathrm{l} \mathrm{ZnCl}_{2}$. The 3 cores were sacrificed after 2,12 , and $24 \mathrm{~h}$ of incubation, respectively. The contribution from anammox to the total $\mathrm{N}_{2}$ production was assessed separately in slurries of the upper 1 to $4 \mathrm{~cm}$ of 1 core mixed with GF/C filtered bottom water (1:1). The slurries in the exetainers were spiked with either (1) ${ }^{15} \mathrm{NO}_{3}{ }^{-}$, (2) ${ }^{15} \mathrm{NH}_{4}{ }^{+}$, or (3) ${ }^{15} \mathrm{NH}_{4}{ }^{+}$and ${ }^{14} \mathrm{NO}_{3}{ }^{-}$ (final concentrations $50 \mu \mathrm{M}$ ). The samples were incubated on a shaking table at in situ temperature, and terminated after $0,1,2,4$, and $7 \mathrm{~d}$ by injecting $100 \mu \mathrm{Z} \mathrm{ZnCl}$. The collected $\mathrm{N}_{2}$ samples were measured using mass spectrometry (Mass Spectrometer: Isotope Ratio Mass Spectrometer Hydra 20-20, SerCon; Autosampler: SerCon; Separation unit: Gas Solid Liquid Sample Prep Unit, ANCA GSL, SerCon) after inserting a helium headspace of $5 \mathrm{ml}$. Denitrification and anammox rates were calculated as described by Risgaard-Petersen et al. (2003).

\section{Sulfate reduction rates}

Sulfate reduction rates (SRRs) were measured in intact cores using the ${ }^{35} \mathrm{~S}$ tracer method (Jørgensen 1978). Three acrylic Plexiglas coreliners $(4.3 \mathrm{~cm}$ i.d., length $30 \mathrm{~cm}$ ) with silicone ports were used to subsample the recovered cores, and the ${ }^{35} \mathrm{~S}$ tracer was injected into the cores at $1 \mathrm{~cm}$ intervals via the silicone ports, starting at a sediment depth of $0.5 \mathrm{~cm}$. The sediment was incubated at in situ temperature in the dark for $8 \mathrm{~h}$ and then sectioned into relevant intervals. Samples were fixed in zinc acetate $(5 \%$ $\mathrm{wt}$ ) and the accumulated reduced ${ }^{35} \mathrm{~S}$ was recovered by cold distillation (Kallmeyer et al. 2004) and quantified by scintillation counting. SRRs were calculated according to standard calculations as derived by Jørgensen (1978), where the reduced ${ }^{35} \mathrm{~S}$ is used to calculate the reduction rates accounting for in situ $\mathrm{SO}_{4}{ }^{2-}$ concentration, the bacterial isotope fractionation, the specific activity of the tracer, and the incubation time. At the beginning of the study in 2011, the following sectioning scheme was applied: $0-1,1-2,2-4,4-6,6-8$, and $8-10 \mathrm{~cm}$; depths of $10-12,12-14$, and $14-16 \mathrm{~cm}$ were added starting from January 2012. The depth-integrated activity from $10-16 \mathrm{~cm}$ depth corresponded to $20 \%$ of the total activity from $0-16 \mathrm{~cm}$ depth, thus the values measured before January 2012 were multiplied by 1.2 to account for the activity of the deeper sediment layers.

\section{Sediment characteristics}

Bulk density and porosity were measured on 3 separate occasions (June, October, and December 2011). Recovered sediment cores were sliced into 1 or $2 \mathrm{~cm}$ sections and the water content was determined as the weight loss after drying for $24 \mathrm{~h}$ at $105^{\circ} \mathrm{C}$. The porosity and solid phase density were calculated from the measured bulk sediment density and water content. Total carbon and organic carbon content was measured on 1 occasion on freeze-dried sediment sectioned similarly as the cores used for density and porosity measurements. Known masses of homogenized sediment from each sample ( 20 mg; an acidified and non-acidified sample) were placed in tin (Sn) capsules and combusted at $600^{\circ} \mathrm{C}$. The $\mathrm{C}$ and $\mathrm{N}$ content of the combustion gas was measured using the isotope ratio mass spectrometer (Isotope Ratio Mass Spectrometer Hydra 20-20, SerCon; Autosampler: SerCon; Separation unit: Gas Solid Liquid Sample Prep Unit, ANCA GSL, SerCon). On 1 occasion (February 2013), 3 sediment cores were retrieved for determination of sediment burial rate based on measured excess of ${ }^{210} \mathrm{~Pb}$. The cores were sectioned into intervals of $0.5 \mathrm{~cm}$ in the top $5 \mathrm{~cm}$, $1 \mathrm{~cm}$ until $10 \mathrm{~cm}$, and $2 \mathrm{~cm}$ through the remainder of the core (core length between 16 and $18 \mathrm{~cm}$ ). Total ${ }^{210} \mathrm{~Pb}$ activity was determined by alpha spectrometry, measuring the granddaughter ${ }^{210} \mathrm{Po}$ (De Stigter et al. 2011). In this method, it is assumed that ${ }^{210} \mathrm{~Pb}$ and ${ }^{210} \mathrm{Po}$ are at equilibrium, and thus ${ }^{210} \mathrm{Po}$ is used as an indicator for ${ }^{210} \mathrm{~Pb}$ activity. ${ }^{210} \mathrm{Po}$ was leached from freeze-dried and homogenized sediment samples with concentrated HCl. Subsequently, the Po isotopes were collected by spontaneous electrochemical deposition on silver disks, and the activity was counted on Canberra Passivated Implanted Planar Silicon (PIPS) detectors (counting time: $3 \mathrm{~d}$ ). The constant ${ }^{210} \mathrm{~Pb}$ flux and sedimentation model (Appleby \& Oldfield 1992), including a surface mixed layer (Nittrouer et al. 1984), was fitted to the observed profile of total ${ }^{210} \mathrm{~Pb}$ activity and plotted against the cumulative mass depth $\left(\mathrm{g} \mathrm{cm}^{-2}\right)$. The fitted model supplied information on the mixing depth (the depth where irrigation becomes insignificant), the diffusive mixing rate as well as the supported and excess ${ }^{210} \mathrm{~Pb}$, which can be considered as the background and sedimentation based ${ }^{210} \mathrm{~Pb}$ fraction, respectively. The sediment burial rate $\left(\mathrm{g} \mathrm{cm}^{-2} \mathrm{yr}^{-1}\right)$ was then derived from these values. As only 1 core had a sufficient length to determine the supported ${ }^{210} \mathrm{~Pb}$ fraction, values from the fit to this core were used when fitting the ${ }^{210} \mathrm{~Pb}$ profiles to the 2 remaining cores. The burial 
velocity $\left(\mathrm{cm} \mathrm{yr}^{-1}\right)$ was calculated based on an exponential decrease in excess ${ }^{210} \mathrm{~Pb}$ depth below $5 \mathrm{~cm}$, assuming that no biological mixing occurs below this depth, as relatively constant concentrations of excess ${ }^{210} \mathrm{~Pb}$ were observed only above $5 \mathrm{~cm}$ (e.g. De Stigter et al. 2011). The sediment burial rate $F_{\text {sed }}=w(1-\varphi)$ $\rho\left(\mathrm{g}\right.$ solids $\mathrm{cm}^{-2} \mathrm{yr}^{-1}$ ) and the carbon burial rate $F_{\mathrm{b}}=w$ $(1-\varphi) \rho \mathrm{C}_{\mathrm{OM}}\left(\mathrm{g} \mathrm{C} \mathrm{cm}^{-2} \mathrm{yr}^{-1}\right)$ were calculated using the burial velocity $w\left(\mathrm{~cm} \mathrm{yr}^{-1}\right)$, the solid phase density $\rho\left(\mathrm{g} \mathrm{cm}^{-3}\right)$, the organic carbon content $\mathrm{C}_{\mathrm{OM}}\left(\mathrm{g} \mathrm{C} \mathrm{g}^{-1}\right)$, and the porosity at the bottom of the sediment core $\varphi$ $(12-16 \mathrm{~cm})$.

\section{RESULTS}

\section{Water column characteristics}

The surface water temperature (0-2 m) increased from $1.9^{\circ} \mathrm{C}$ in May 2011 to a maximum of $11.0^{\circ} \mathrm{C}$ in July and subsequently decreased to $-0.8^{\circ} \mathrm{C}$ in February 2012. Sea ice formed in February 2012 and covered the inner part of the fjord until mid-April 2012. The thickness of the ice was $\sim 40 \mathrm{~cm}$ in mid-March. The bottom water temperature varied from a maximum of $2.9^{\circ} \mathrm{C}$ in November 2011 to a minimum of $-0.8^{\circ} \mathrm{C}$ in February 2012 (Fig. 2A). The salinitydepth-time isopleth reflects surface freshening during summer (Fig. 2B), mainly driven by advection of fresher water into the fjord. Turbulent mixing created by tidal forcing gradually dispersed the fresher surface water towards the bottom, e.g. the $1026.5 \mathrm{~kg} \mathrm{~m}^{-3}$ isopycnal moved from $18 \mathrm{~m}$ depth in June to $45 \mathrm{~m}$ in September and to $90 \mathrm{~m}$ in November (Fig. 2C). However, the slow downward freshening of the water column did not reach the bottom waters before late November, and the $\sim 17 \mathrm{~m}$ thick bottom layer remained isolated for almost 5 mo. The stratification parameter (Fig. 2D) increased from $161 \mathrm{~J} \mathrm{~m}^{-3}$ in May to $878 \mathrm{~J} \mathrm{~m}^{-3}$ in August 2011, showing an increasing amount of energy needed to mix the water column during the late summer. From September 2011, the stratification parameter decreased again, reaching a minimum in December (Fig. 2D), where the water column was fully mixed. This mixed state was maintained until late spring, when increased atmospheric heating and freshwater advection re-induced stratification at the surface. The stagnant conditions in the deep bottom water resulted in an almost linear decline in $\mathrm{O}_{2}$ concentration (mean $\pm \mathrm{SD}, 0.73 \pm 0.05 \mu \mathrm{mol} \mathrm{l}^{-1}$ $\mathrm{d}^{-1}$ ) from July to November, when a minimum value of $229 \mu \mathrm{mol} \mathrm{l^{-1 }}$ (66\% air saturation) was reached (Fig. 2E). Considering the deeper waters in the basin
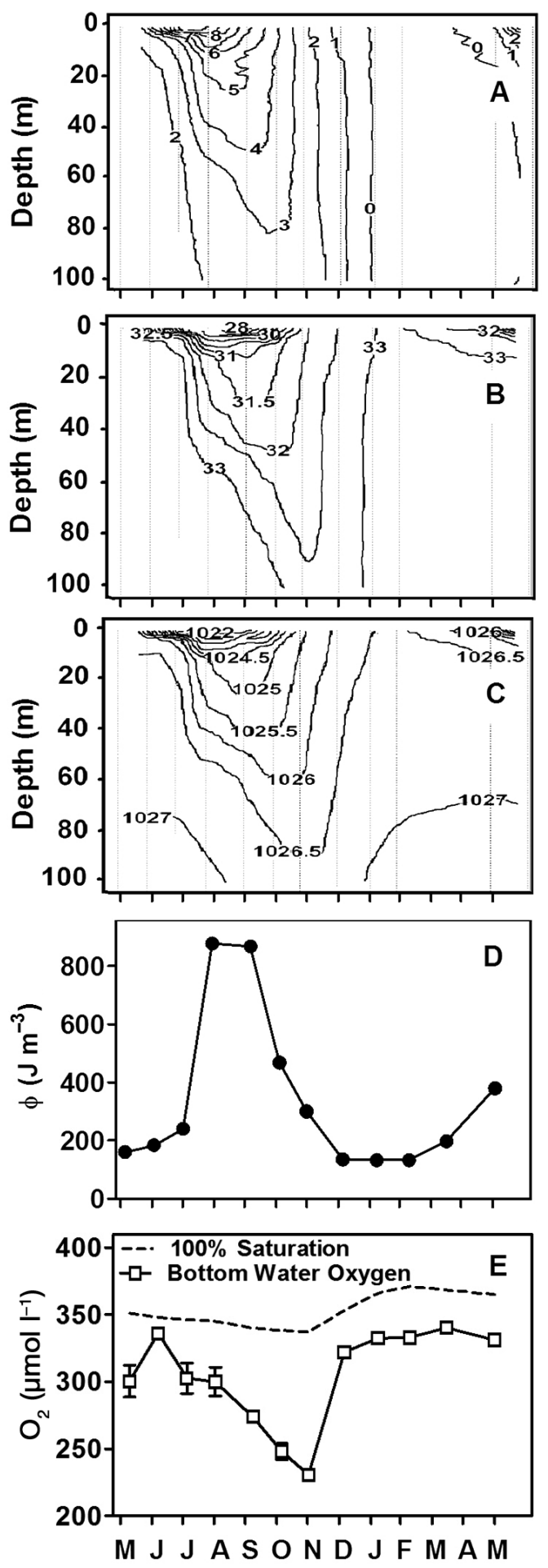

Fig. 2. Seasonal variations in (A) temperature $\left({ }^{\circ} \mathrm{C}\right)$, (B) salinity, and $(\mathrm{C})$ density $\left(\rho, \mathrm{kg} \mathrm{m}^{-3}\right)$ of the water column at the study site in Kobbefjord. The time of each sampling session is indicated by the thin vertical lines. (D) Seasonal variation in the stratification parameter $\phi\left(\mathrm{J} \mathrm{m}^{-3}\right)$ calculated from the water column density. (E) Bottom water $\mathrm{O}_{2}$ concentrations $(\mathrm{n}=6)$ at the study site, with the dashed line indicating the $\mathrm{O}_{2}$ concentration at $100 \%$ air-saturation 
as a closed system during that period, the decline in $\mathrm{O}_{2}$ concentration in the bottom $17 \mathrm{~m}$ (the depth zone that remained hydrodynamically isolated) corresponded to a total basin-wide $\mathrm{O}_{2}$ consumption of $12.4 \pm$ $0.9 \mathrm{mmol} \mathrm{m}^{-2} \mathrm{~d}^{-1}$. This value integrates both respiration in the bottom water and benthic $\mathrm{O}_{2}$ consumption, but may be considered as a minimum value, as a minor amount of $\mathrm{O}_{2}$ would have entered the bottom waters from above through turbulent mixing.

The depth-integrated gross primary production showed a distinct seasonal pattern, with peak activity of $\sim 50.0 \pm 6.4 \mathrm{mmol} \mathrm{C} \mathrm{m}^{-2} \mathrm{~d}^{-1}$ in May 2011 and 2012 and almost no activity during the winter (Fig. 3A). Mid-summer and early autumn were characterized by intermediate primary production rates, and the annual rate amounted to $7.2 \pm 0.5 \mathrm{~mol} \mathrm{C} \mathrm{m}^{-2} \mathrm{yr}^{-1}$. Maximum

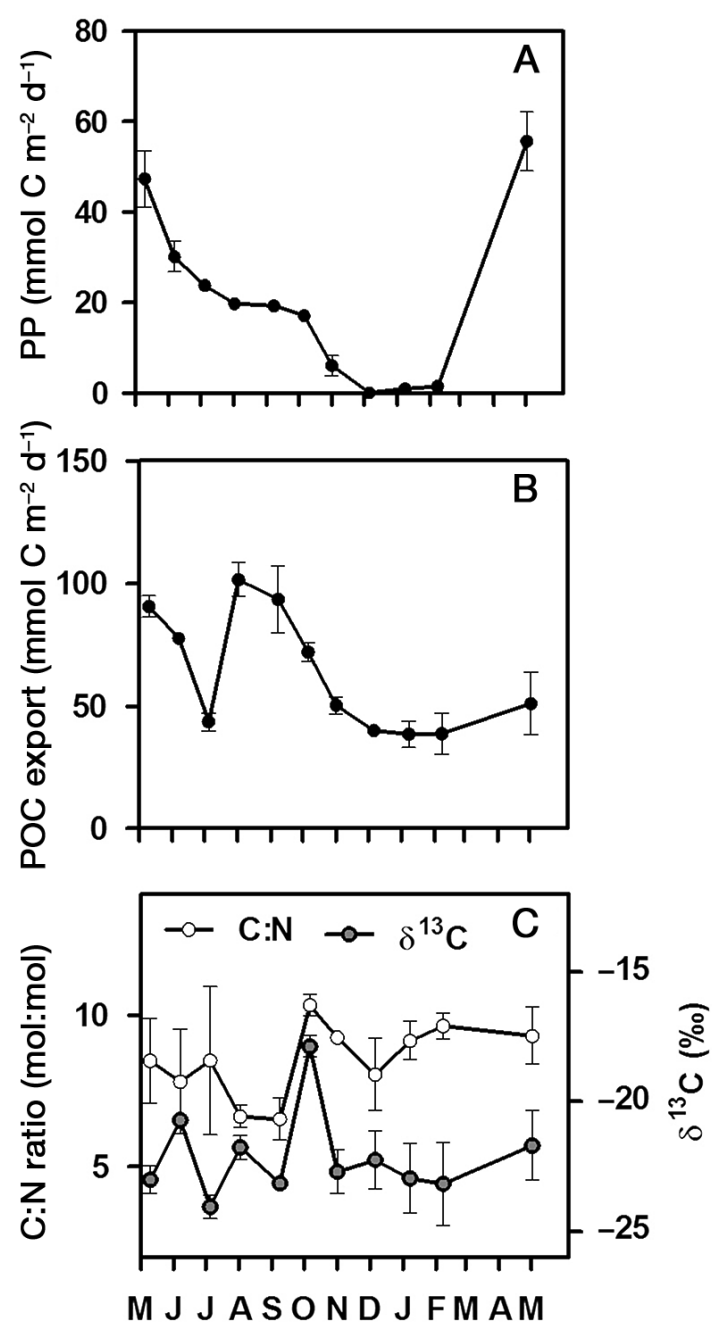

Fig. 3. Seasonal variations in (A) depth-integrated primary production (PP), (B) particulate organic carbon (POC) export, and $(\mathrm{C})$ the $\mathrm{C}: \mathrm{N}$ ratio (mol:mol) and $\delta^{13} \mathrm{C}(\%)$ values of the material sampled by 2 parallel sediment traps. Error bars indicate the difference between duplicates $(n=2)$
POC export was observed during May, August, and September, indicating a partial decoupling between primary production and POC export through the water column. Particulate inorganic carbon (PIC) only accounted for $6 \pm 4 \%$ on average of the total amount of the total particulate carbon in the traps, with no seasonal trend in the relative contribution from PIC. Over the year, the export of POC varied by a factor of 2.5 with a minimum of $38.7 \pm 5.4 \mathrm{mmol} \mathrm{C} \mathrm{m}^{-2} \mathrm{~d}^{-1}$ during winter, and a maximum of $101.5 \pm 7.0 \mathrm{mmol} \mathrm{C} \mathrm{m}^{-2}$ $\mathrm{d}^{-1}$ during summer. Accordingly, the POC export during winter remained substantial at a time when primary production was almost negligible. The annual integrated rate of POC export amounted to $19.9 \pm$ $2.9 \mathrm{~mol} \mathrm{C} \mathrm{m}^{-2} \mathrm{yr}^{-1}$, which exceeds the annual rate of primary production by a factor of 2.8 (Fig. 3B). The molar $\mathrm{C}: \mathrm{N}$ ratios of the sedimentating material ranged between $8.0 \pm 1.2$ and $10.3 \pm 0.3$, which is slightly above the Redfield ratio, while the measured $\delta^{13} \mathrm{C}$ values ranged between $-17.4 \pm 0.4$ and $-24.0 \pm 0.5 \%$ (Fig. 3C). These values suggest that the settling material was mainly derived from marine phytodetritus and not from terrestrial sources (France 1995).

\section{Sediment characteristics}

The muddy sediment had a surface porosity of $0.86 \pm 0.02$ that gradually decreased to $0.68 \pm 0.01$

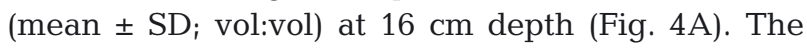
bulk density at the corresponding depths increased from $1.30 \pm 0.09$ to $1.54 \pm 0.04 \mathrm{~g} \mathrm{~cm}^{-3}$ (Fig. $4 \mathrm{~A}$ ) and the solid phase density at $12-16 \mathrm{~cm}$ was $2.7 \mathrm{~g} \mathrm{~cm}^{-3}$. The organic carbon content decreased from $4.2 \%$ in the sediment surface layer $(0-1 \mathrm{~cm})$ to $3.8 \%$ at depth (14$16 \mathrm{~cm}$ ). On average, the sediment inorganic fraction corresponded to $13 \pm 5 \%$ of the organic carbon. Excess ${ }^{210} \mathrm{~Pb}$ was relatively constant in the upper $5 \mathrm{~cm}$, indicating substantial sediment mixing. Below $5 \mathrm{~cm}$, excess ${ }^{210} \mathrm{~Pb}$ declined exponentially (Fig. 4B), and the calculated burial velocity was $0.17 \pm 0.05 \mathrm{~cm} \mathrm{yr}^{-1}$, which corresponds to a sediment burial rate of $1412 \pm 446 \mathrm{~g} \mathrm{~m}^{-2}$ $\mathrm{yr}^{-1}$. Using the carbon content ( $\mathrm{g} \mathrm{C} \mathrm{g}^{-1}$ sediment) from the bottom of the sediment core, the sediment burial rate corresponds to a carbon burial rate of $63 \pm 20 \mathrm{~g} \mathrm{C}$ $\mathrm{m}^{-2} \mathrm{yr}^{-1}$ (equivalent to $5.3 \mathrm{~mol} \mathrm{C} \mathrm{m}^{-2} \mathrm{yr}^{-1}$ ).

\section{Benthic oxygen dynamics and DIC exchange rates}

Oxygen penetration depth remained relatively constant at around $6 \pm 1 \mathrm{~mm}$ from May to November 2011, and deepened in winter to reach a maximum of 

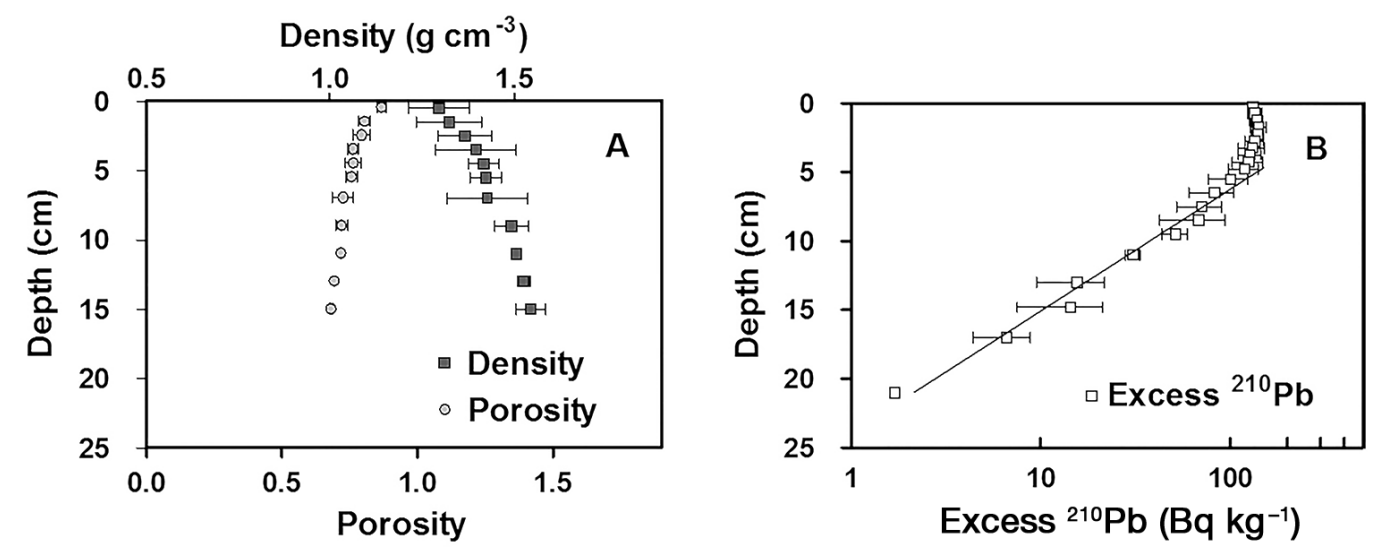

Fig. 4. (A) Depth profiles of bulk sediment density $\left(\mathrm{g} \mathrm{cm}^{-3}\right)$ and porosity $(\varphi)$ from the surface layer $(0-1 \mathrm{~cm})$ to a depth of $16 \mathrm{~cm}$ $(\mathrm{n}=6)$. (B) Excess ${ }^{210} \mathrm{~Pb}\left(\mathrm{~Bq} \mathrm{~kg}{ }^{-1}\right)$ depth profile from the surface to $20 \mathrm{~cm}$ sediment depth $(\mathrm{n}=3)$. Error bars indicate $\mathrm{SD}$

$9 \pm 1 \mathrm{~mm}$ in February 2012 (Fig. 5). The DOU ranged from 2.8 to $6.8 \mathrm{mmol} \mathrm{m}^{-2} \mathrm{~d}^{-1}$, with an average annual value of $4.8 \mathrm{mmol} \mathrm{m}^{-2} \mathrm{~d}^{-1}$, but the rates did not exhibit a distinct seasonal pattern. The total oxygen uptake (TOU) in the sediment ranged from $11.4 \mathrm{mmol} \mathrm{m}^{-2} \mathrm{~d}^{-1}$ in May 2011 to $5.5 \mathrm{mmol} \mathrm{m}^{-2} \mathrm{~d}^{-1}$ in February 2011, indicating a seasonal pattern (Fig. 6A) that partly followed the dynamics in the supply of POC, with peaks in TOU appearing approximately 1 mo after peaks in POC export. Reduced $\mathrm{O}_{2}$ availability in the bottom water during summer (Fig. 2E) may partially have limited $\mathrm{O}_{2}$ uptake, leading to a transient accumulation of reduced iron and sulfur in the sediment during that period. The DOU contribution to the TOU was higher during winter months (69\%) compared to summer months (52\%), which could suggest a reduced faunal activity during the low deposition period of winter (Fig. 6A). Exchange rates of DIC generally followed the seasonal pattern of the TOU, with the highest rates measured during the summer (Fig. 6B). The sediment respiration quotient (RQ: DIC/TOU) reached a maximum of 1.3 during spring
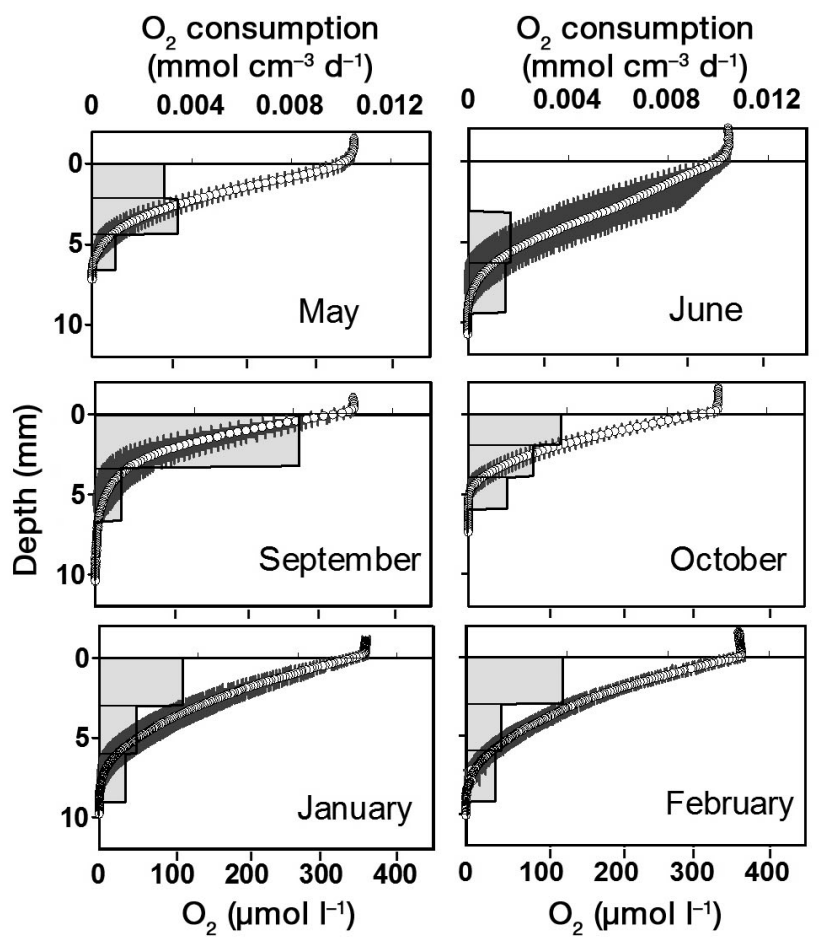

$\mathrm{O}_{2}$ consumption $\begin{array}{lll}0.004 & 0.008 & 0.012\end{array}$
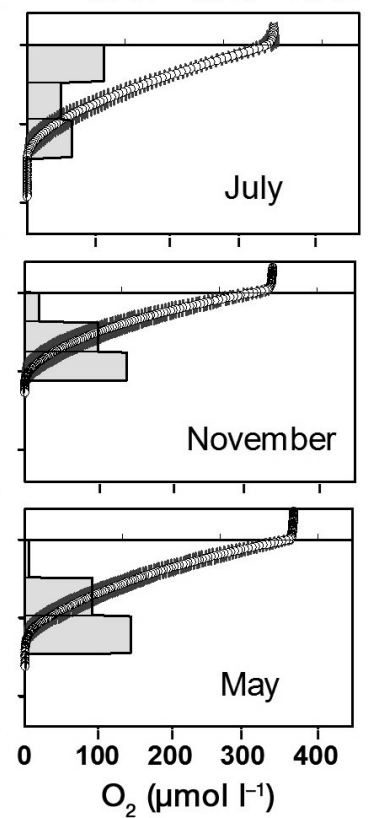

$\mathrm{O}_{2}$ consumption $\left(\mathrm{mmol} \mathrm{cm} \mathrm{C}^{-3} \mathrm{~d}^{-1}\right)$
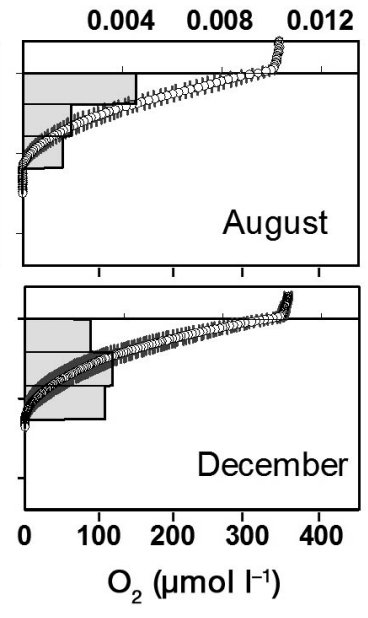

Fig. 5. Seasonal variation in benthic $\mathrm{O}_{2}$ concentration profiles (open circles, $\mu \mathrm{mol} \mathrm{l}^{-1}$ ) and $\mathrm{O}_{2}$ consumption (bars, mmol $\mathrm{cm}^{-3}$ $\mathrm{d}^{-1}$ ) as modeled from the concentration profile using the software package 'PROFILE' (Berg et al. 1998). Error bars indicate SD of the concentrations measured at each sediment depth $(\mathrm{n}=6-12)$ 

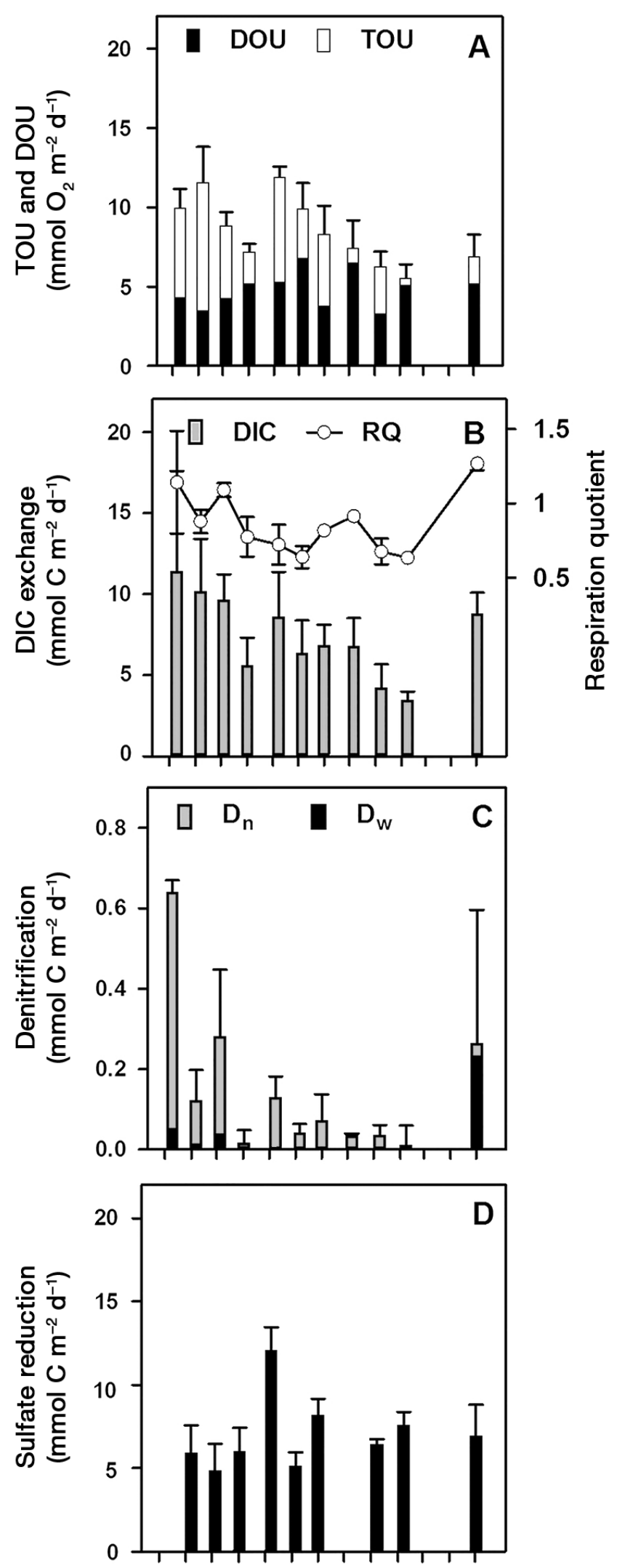

M J J A SOND J F MAM and a minimum of 0.6 during winter. The annual average in $\mathrm{RQ}$ amounted to $0.9 \pm 0.2$ and did not differ significantly from 1.0 (Fig. 6B). The annual benthic $\mathrm{O}_{2}$ uptake amounted to $3.2 \pm 0.6 \mathrm{~mol} \mathrm{~m}^{-2} \mathrm{yr}^{-1}$, while the annual DIC release was $2.9 \pm 0.8 \mathrm{~mol} \mathrm{C} \mathrm{m}^{-2} \mathrm{yr}^{-1}$.

\section{Denitrification, anammox, and SRRs}

Denitrification rates during summer ranged between 200 and $600 \mu \mathrm{mol} \mathrm{N} \mathrm{m}{ }^{-2} \mathrm{~d}^{-1}$, while rates during winter declined to $15-106 \mu \mathrm{mol} \mathrm{N} \mathrm{m}{ }^{-2} \mathrm{~d}^{-1}$ (Fig. 6C). Denitrification was mainly sustained by nitrification, especially during winter, when the process provided $92 \%$ of the $\mathrm{NO}_{3}{ }^{-}$being reduced by denitrification. Anammox only accounted for a minor part of the annual integrated $\mathrm{N}_{2}$ production, with a maximum value of $19 \%$ during October (annual average 1\%). No seasonal trend could be observed for the relative contribution of $\mathrm{N}_{2}$ production by anammox (data not shown). SRRs were suppressed at the sediment surface and reached maximum values between 2 and $6 \mathrm{~cm}$ depth (data not shown). The depth-integrated SRRs were relatively high at 3 to $8 \mathrm{mmol} \mathrm{SO}_{4}{ }^{2-} \mathrm{m}^{-2}$ $\mathrm{d}^{-1}$ and showed no seasonal trend (Fig. 6D).

\section{DISCUSSION}

The overall research aim of our study was to evaluate and discuss future developments of the biogeochemical cycling in Arctic fjords following projected reduction in sea-ice coverage. To place our results in a regional context, we use data from the Marine Basic Nuuk monitoring program, which has provided monthly measurements of pelagic productivity and

Fig. 6. (A) Average diffusive oxygen uptake (DOU, $\mathrm{mmol}_{2}$ $\mathrm{m}^{-2} \mathrm{~d}^{-1}, \mathrm{n}=6-12$ ) and average total oxygen uptake (TOU, mmol $\mathrm{O}_{2} \mathrm{~m}^{-2} \mathrm{~d}^{-1}, \mathrm{n}=6$ ) measured on 11 occasions between May 2011 and May 2012. Error bars indicate SD. (B) Seasonal variation in the exchange rate of dissolved inorganic carbon (DIC, mmol C m${ }^{-2} \mathrm{~d}^{-1}, \mathrm{n}=3-6$ ). The calculated respiration quotient $(\mathrm{RQ}=\mathrm{DIC} / \mathrm{TOU})$ is indicated by the open circles $(n=3-6)$. (C) Seasonal variation in the benthic denitrification rates expressed in carbon equivalents $\left(\mathrm{mmol} \mathrm{C} \mathrm{m}{ }^{-2}\right.$ $\mathrm{d}^{-1}, \mathrm{n}=3$ ) accounting for the stoichiometry $\left(1 \mathrm{CO}_{2}: 0.8 \mathrm{NO}_{3}\right)$, with $\mathrm{D}_{\mathrm{n}}$ indicating the amount of denitrification sustained by nitrification, while $\mathrm{D}_{\mathrm{w}}$ represents the denitrification based on $\mathrm{NO}_{3}{ }^{-}$from the bottom water. Error bars indicate SD. (D) Seasonal variation in the sulfate reduction rates at the study site expressed in carbon equivalents $\left(\mathrm{mmol} \mathrm{C} \mathrm{m}^{-2} \mathrm{~d}^{-1}, \mathrm{n}=3\right.$ ) accounting for the stoichiometry $\left(1 \mathrm{CO}_{2}: 0.5 \mathrm{SO}_{4}{ }^{2-}\right)$ 
carbon export in the outer sill region in Godthåbsfjord since 2005 (annual reports: e.g. Jensen \& Rasch 2012). In the following sub-sections the monitoring data are related to data collected in Kobbefjord, and an annual integrated carbon budget for our study site is established and discussed in the context of carbon cycling in Arctic fjords.

\section{Pelagic primary production and export rates of the outer sill region in Godthåbsfjord and Kobbefjord}

The depth-integrated annual primary production at the main monitoring station in Godthåbsfjord (Fig. 1B) varied between 7.1 and $11.6 \mathrm{~mol} \mathrm{C} \mathrm{m}{ }^{-2} \mathrm{yr}^{-1}$ over the period 2005 to 2012 (Juul-Pedersen et al. 2015). The primary production typically exhibited 2 distinctive peaks in May and August, with timing and size regulated by the availability of light and nutrients (Juul-Pedersen et al. 2015). The first production peak is triggered by stratification following runoff during spring. The second production peak is associated with the transport of high phytoplankton biomass from the glacier front in Godthåbsfjord, where the production is fuelled by nutrient replenishment induced by a subsurface release of low-density glacial meltwater (Juul-Pedersen et al. 2015, Meire et al. 2015). In contrast to Godthåbsfjord, the pelagic productivity within Kobbefjord is mainly governed by the seasonal sea-ice coverage and freshwater input from outside the fjord, leading to a single productivity peak during spring (Fig. 3). Our estimate of annual primary production corresponded to $7.2 \pm 0.5 \mathrm{~mol} \mathrm{C} \mathrm{m}^{-2}$ $\mathrm{yr}^{-1}$ (Fig. 7) and is therefore comparable to the annual integrated productivity at the outer sill region in Godthåbsfjord. A compilation of the available data on annual primary production from fjords and coastal areas in Greenland strongly indicates an attenuation in productivity with increasing latitude (Table 1). This aligns well with a previous compilation that included open water areas from the entire Arctic and suggested a close relationship between pelagic productivity and the duration of the ice-free period (Rysgaard et al. 1999, 2003).
Surprisingly, all available measurements from Greenlandic fjords indicate that POC export cannot be sustained by local primary production (Table 1). Based on the present data from Kobbefjord, the POC export was $19.9 \pm 2.5 \mathrm{~mol} \mathrm{C} \mathrm{m}{ }^{-2} \mathrm{yr}^{-1}$, which is 2.8 times the local primary production (Table 1). Similar observations have been made in the outer sill region in Godthåbsfjord, where total carbon export is on average $27.0 \pm 4.4 \mathrm{~mol} \mathrm{C} \mathrm{m} \mathrm{C}^{-1}$, which is 3.1 times higher than the average local primary production $\left(9.3 \pm 1.4 \mathrm{~mol} \mathrm{C} \mathrm{m}^{-2} \mathrm{~d}^{-1}\right.$; Rysgaard et al. 2012, JuulPedersen et al. 2015). This suggests a significant horizontal import of carbon to both sites, as the $\mathrm{C}: \mathrm{N}$ ratio and the $\delta^{13} \mathrm{C}$ values of sedimentating material in both Kobbefjord and recent measurements from Godthåbsfjord (2010-2012, annual reports, e.g. Jensen \& Rasch 2012) strongly suggest that this material is of marine origin. In Kobbefjord, the material is most likely imported from Godthåbsfjord via local currents (Mortensen et al. 2011) driven by an ingoing subsurface mass transport above the sill at $30 \mathrm{~m}$ water depth (Fig. 1C; J. Mortensen et al. unpubl. results). This is

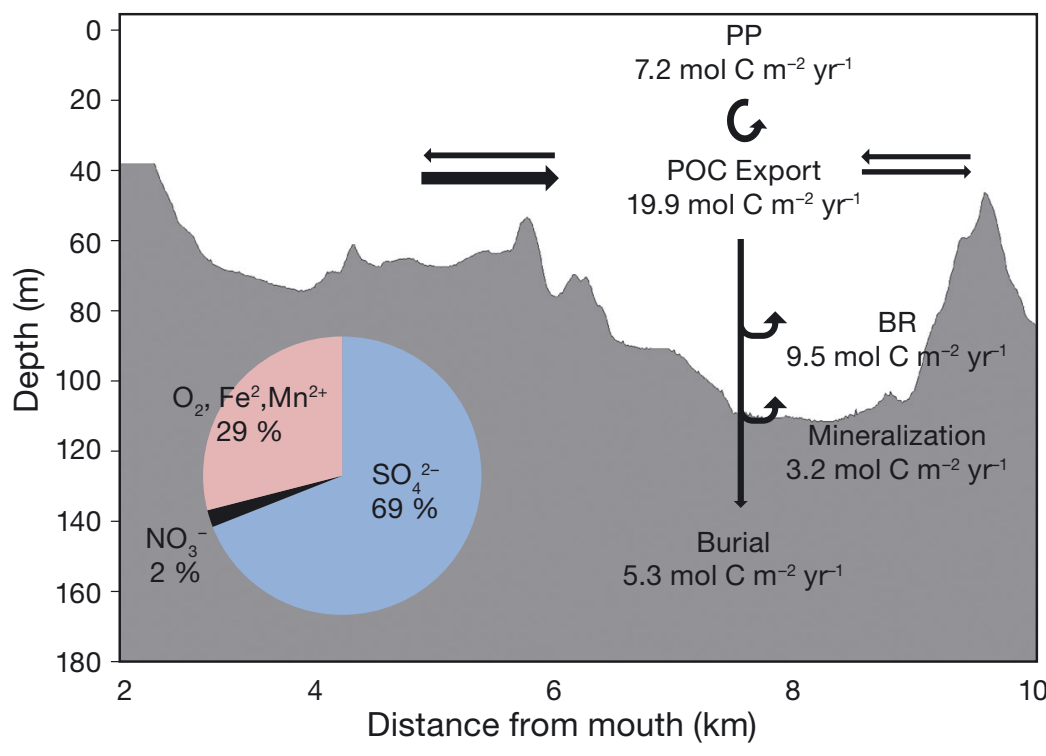

Fig. 7. Annual integrated carbon budget at the study site, including both pelagic and benthic processes. Primary production (PP) rates, particulate organic carbon (POC) export, carbon mineralization, and carbon burial rates are based on independently measured rates, while the pelagic bacterial respiration (BR) rates were calculated from the $\mathrm{O}_{2}$ decline in the bottom water from July to November (Fig. 2E) scaled to the seasonality as measured by Middelboe et al. (2012). Horizontal arrows indicate the advection of POC towards and away from the basin, with the thickness indicating the relative amount of transported material. The budget is depicted against the background of a length transect showing the bathymetry of central Kobbefjord. The pie chart indicates the relative contribution to total carbon mineralization by the respective diagenetic pathways from aerobic respiration and iron and manganese reduction $\left(\mathrm{O}_{2}\right.$, $\left.\mathrm{Fe}^{2+}, \mathrm{Mn}^{2+}\right)$, denitrification $\left(\mathrm{NO}_{3}{ }^{-}\right)$, and sulfate reduction $\left(\mathrm{SO}_{4}{ }^{2-}\right)$ 
Table 1. Compiled values for the duration of ice-free periods, annual rates of primary production (PP), and sedimentation of particulate organic carbon (POC) as extracted from available studies in Greenlandic fjords

\begin{tabular}{|c|c|c|c|c|c|}
\hline Study site & $\begin{array}{l}\text { Latitude } \\
\qquad(\mathrm{N})\end{array}$ & $\begin{array}{l}\text { Longitude } \\
\text { (W) }\end{array}$ & $\begin{array}{l}\text { Ice-free period } \\
\text { (d) }\end{array}$ & $\begin{array}{c}\mathrm{PP} \\
\left(\mathrm{mol} \mathrm{C} \mathrm{m} \mathrm{m}^{-2} \mathrm{yr}^{-1}\right)\end{array}$ & $\begin{array}{l}\text { POC export } \\
\left(\mathrm{mol} \mathrm{C} \mathrm{m}^{-2} \mathrm{yr}^{-1}\right)\end{array}$ \\
\hline Kobbefjord & $64^{\circ} 10.48^{\prime}$ & $51^{\circ} 31.27^{\prime}$ & $300^{\mathrm{a}}$ & $7.2^{\mathrm{a}}$ & $19.9^{\mathrm{a}}$ \\
\hline Godthåbsfjord & $64^{\circ} 07.00^{\prime}$ & $51^{\circ} 53.00^{\prime}$ & $365^{\mathrm{b}}$ & $9.3^{\mathrm{b}}$ & $27.0^{\mathrm{b}}$ \\
\hline Disko Bay & $69^{\circ} 15.00^{\prime}$ & $53^{\circ} 33.00^{\prime}$ & $182^{\mathrm{c}}$ & $2.2^{\mathrm{d}}$ & $7.0^{\mathrm{e}}$ \\
\hline Kangikerdlak & $69^{\circ} 27.20^{\prime}$ & $53^{\circ} 35.00^{\prime}$ & $182^{\mathrm{c}}$ & $2.7^{\mathrm{f}}$ & - \\
\hline Young Sound & $74^{\circ} 18.58^{\prime}$ & $20^{\circ} 15.04^{\prime}$ & $80^{9}$ & $0.9^{h}$ & $1.4^{\mathrm{i}}$ \\
\hline Jørgen Brønlund Fjord & $82^{\circ} 07.50^{\prime}$ & $29^{\circ} 53.30^{\prime}$ & $42^{\mathrm{j}}$ & $0.9^{\mathrm{k}}$ & - \\
\hline \multicolumn{6}{|l|}{ aPresent study } \\
\hline \multicolumn{6}{|c|}{$\begin{array}{l}{ }^{\mathrm{b}} \text { Data from the annual reports of the monitoring program Marine Basic Nuuk (e.g. Jensen \& Rasch 2012). All values are } \\
\text { averages for the period } 2005 \text { to } 2012\end{array}$} \\
\hline \multicolumn{6}{|c|}{ 'Average from 1979 to 2003 as reported by Sejr et al. (2007) } \\
\hline \multicolumn{6}{|c|}{ dAnnual rates from Levinsen \& Nielsen (2002) } \\
\hline \multicolumn{6}{|c|}{$\begin{array}{l}\text { eAverage annual rate of POC export estimated from Sejr et al. (2007). The total POC export from } 9 \text { days in May and } 9 \text { days } \\
\text { in September amounted to } 1.3 \mathrm{~mol} \mathrm{C} \mathrm{m}{ }^{-2} \text {, extrapolating these data by a weighted average amounted to } 12.7 \mathrm{~mol} \mathrm{C} \mathrm{m}^{-2} \mathrm{yr}^{-1} \text {, } \\
\text { assuming POC export only occurred during the ice-free period (182 d) }\end{array}$} \\
\hline \multicolumn{6}{|c|}{ f Annual rates from Andersen (1981) } \\
\hline \multicolumn{6}{|c|}{${ }^{9}$ Estimated ice-free period from Rysgaard \& Glud (2007) } \\
\hline \multicolumn{6}{|c|}{${ }^{\mathrm{h}}$ Annual rates from Rysgaard et al. (1999) } \\
\hline \multicolumn{6}{|c|}{ iAnnual rates from Rysgaard \& Sejr (2007) } \\
\hline \multicolumn{6}{|c|}{ jEstimated sea-ice-free period ( 6 wk) from Andersen (1977) } \\
\hline${ }^{\mathrm{k}}$ Average rates from An & $(1977)$ & & & & \\
\hline
\end{tabular}

supported by the annual trend observed in the total carbon export dynamics in the outer sill region in Godhåbsfjord, which align well with the POC export dynamics in Kobbefjord (annual reports, e.g. Jensen \& Rasch 2012). Similar transport processes have been suggested for Young Sound (NE Greenland; Table 1) to explain the apparent net import of organic material from the Greenland Sea (Rysgaard \& Sejr 2007). Consequently, the additional horizontal import of organic material will lead to an extended period of vertical export that does not necessarily reflect the dynamics of the local primary production. In fact, net import of marine organic material is probably a characteristic feature of most Greenlandic fjords, resulting from a large terrestrial runoff and glacial discharge that drives an estuarine circulation with outflowing fresher water in a relatively thin surface layer and a compensating deeper inflow of saltier water (Mortensen et al. 2011, Bendtsen et al. 2014). The imported material will be focused in the central basins due to a net down-slope material transport (Wassmann 1984), which may further induce the imbalance between local surface production and net carbon deposition. Additionally, substantial local benthic primary production might supply organic carbon to the deeper parts of the fjord through lateral transport processes (Krause-Jensen et al. 2012, Attard et al. 2014).

\section{Assessment of pelagic mineralization}

From July to November 2011, the bottom water of the central basin remained isolated. The linear $\mathrm{O}_{2}$ decline in this water mass (90-107 m) corresponded to a total $\mathrm{O}_{2}$ consumption of $12.4 \pm 0.9 \mathrm{mmol} \mathrm{m}^{-2} \mathrm{~d}^{-1}$. During the same period, the measured benthic $\mathrm{O}_{2}$ consumption amounted to $9.4 \mathrm{mmol} \mathrm{m}^{-2} \mathrm{~d}^{-1}$ and the excess consumption of $3.0 \mathrm{mmol} \mathrm{m}^{-2} \mathrm{~d}^{-1}$ in the basin was therefore attributed to the pelagic respiration in the bottom $17 \mathrm{~m}$ water column of the basin, providing a volumetric respiration rate of $0.18 \mu \mathrm{mol} \mathrm{l}^{-1} \mathrm{~d}^{-1}$. Assuming that this pelagic mineralization rate reflects the activity of the entire non-photic water column, the pelagic net mineralization during these $5 \mathrm{mo}$ amounted to a total of $1.6 \mathrm{~mol} \mathrm{C} \mathrm{m}^{-2}$ (assuming an RQ of 1.0). A previous study in Kobbefjord showed a distinct seasonality in the pelagic bacterial carbon demand in the non-photic water column, with estimated $\mathrm{O}_{2}$ consumption rates of $0.17,0.04$, and $0.67 \mu \mathrm{mol} \mathrm{l}^{-1} \mathrm{~d}^{-1}$ in September, February, and May, respectively (Middelboe et al. 2012). In that study, the seasonality in bacterial respiration clearly reflected the productivity of the surface water, and Middelboe et al.'s (2012) September value closely resembles our rate derived from July to November $\left(0.18 \pm 0.05 \mu \mathrm{mol} \mathrm{l}^{-1} \mathrm{~d}^{-1}\right)$. Assuming the same annual variation during our study as in Middelboe et al. 
(2012) and an RQ of 1.0, the annual pelagic depthintegrated $\mathrm{O}_{2}$ consumption below the photic zone (where light intensity is $<1 \%$ of the measured intensity at the surface) corresponded to $9.5 \mathrm{~mol} \mathrm{C} \mathrm{m}{ }^{-2} \mathrm{yr}^{-1}$ (Fig. 7). This activity was sustained by both DOC and POC, but a simple mass balance calculation suggests that at least $52 \%$ of the POC sampled at $60 \mathrm{~m}$ water depth $\left(10.4=19.9-9.5 \mathrm{mmol} \mathrm{C} \mathrm{m}{ }^{-2} \mathrm{yr}^{-1}\right)$ reached the sediment at $107 \mathrm{~m}$ depth (Fig. 7) to undergo either benthic mineralization or burial.

\section{Benthic carbon mineralization and burial in Kobbefjord}

The Marine Basic Nuuk monitoring program (e.g. Jensen \& Rasch 2012) quantifies TOU and DOU 4 times a year in the sediment of the inner basin of Kobbefjord, $2.4 \mathrm{~km}$ from our study site (Fig. 1B,C). These measurements were conducted in February, May, August, and November during 6 successive years (2006-2011), and, assuming that each TOU value reflects conditions over $3 \mathrm{mo}$, the average annual benthic $\mathrm{O}_{2}$ consumption rate amounts to $2.5 \pm$ $0.4 \mathrm{~mol} \mathrm{~m}^{-2} \mathrm{yr}^{-1}(\mathrm{n}=6)$. This is slightly lower than the annual $\mathrm{O}_{2}$ consumption rate of $3.2 \pm 0.6 \mathrm{~mol} \mathrm{~m}^{-2} \mathrm{yr}^{-1}$ found at our study site, although it is not statistically significantly different (Fig. 7). The trend showing a lower annual TOU rate at the monitoring station compared to our station could suggest a gradient in deposition of the marine organic material being transported to our study site from outside Kobbefjord, with less material reaching the inner basin (Nuuk basic sediment monitoring station) compared to our study site.

In contrast to the pelagic primary production and POC export, the benthic $\mathrm{O}_{2}$ uptake in Kobbefjord only exhibited modest seasonality (Fig. 6), which was also apparent from the monitoring program in the inner basin. In the present study, the slightly elevated benthic consumption of $\mathrm{O}_{2}$ during summer coincided with a minimum in the oxygen penetration depth and low $\mathrm{O}_{2}$ concentrations in the bottom waters. Thus, $\mathrm{O}_{2}$ consumption rate was more strongly limited by low $\mathrm{O}_{2}$ availability at this time. DIC exchange rates exhibited a more pronounced seasonality, resulting in RQ values ranging from 1.3 during summer to 0.6 during winter. As the PIC fraction in the sediment $(12 \pm 4 \%)$ was higher compared to the fraction in the sedimentating total carbon (TC, $6 \pm$ $4 \%$ ), the DIC release was dominated by mineralization rather than e.g. $\mathrm{CaCO}_{3}$ dissolution. It is therefore unlikely that the RQ values were strongly affected by
PIC. Hence, the higher RQ values during the spring and summer instead suggest that an 'oxygen debt' of reduced iron and sulfur, in the form of $\mathrm{FeS}$ and $\mathrm{FeS}_{2}$, accumulated transiently in the sediment (Therkildsen \& Lomstein 1993). These pools were likely reoxidized during winter as input of organic material declined and $\mathrm{O}_{2}$ availability improved, resulting in a low RQ. This dynamic dampened seasonal variations in the benthic $\mathrm{O}_{2}$ consumption, which was partly decoupled from the dynamics in the benthic carbon mineralization. On average, the RQ value was $0.9 \pm$ 0.2 , indicating limited annual net accumulation of reduced chemical species (i.e. FeS and $\mathrm{FeS}_{2}$ ). Annually, the carbon mineralization rate amounted to $3.2 \mathrm{~mol} \mathrm{C} \mathrm{m}{ }^{-2} \mathrm{yr}^{-1}$, which corresponds to $31 \%$ of the organic carbon deposition of $10.4 \mathrm{~mol} \mathrm{C} \mathrm{m} \mathrm{Cr}^{-1}$ (POC export: 19.9 minus pelagic respiration: $9.5 \mathrm{~mol}$ $\mathrm{C} \mathrm{m}^{-2} \mathrm{yr}^{-1}$ ) estimated to reach the sediment (Fig. 7).

In a previous compilation, benthic carbon mineralization rates of 28 marine studies exhibited a clear relation to the sediment burial rate (Canfield 1989). Our observed sediment burial rate of $0.14 \mathrm{~g} \mathrm{~cm}^{-2} \mathrm{yr}^{-1}$ and total benthic mineralization rate of $3.2 \pm 0.6 \mathrm{~mol}$ $\mathrm{C} \mathrm{\textrm {m } ^ { - 2 }} \mathrm{yr}^{-1}$ matched the relation of the compiled data and, hence, does not indicate a pronounced impact of the Arctic setting on mineralization efficiency. Our measured annual SRR was equivalent to a carbon oxidation rate of $2.2 \pm 0.7 \mathrm{~mol} \mathrm{C} \mathrm{m}^{-2} \mathrm{yr}^{-1}$ (assuming a stoichiometry of $1 \mathrm{CO}_{2}: 0.5 \mathrm{SO}_{4}{ }^{-2}$ ), corresponding to $69 \%$ of the annual carbon mineralization (3.2 mol C $\mathrm{m}^{-2} \mathrm{yr}^{-1}$, Fig. 7). This compares well to other coastal environments with similar burial rates of organic material in both the temperate and the Arctic region (e.g. Iversen \& Jørgensen 1985, Jørgensen 1996, Kostka et al. 1999; 0.10-0.47 $\mathrm{g} \mathrm{cm}^{-2} \mathrm{yr}^{-1}$ ).

Denitrification accounted for $99 \%$ of the annual benthic $\mathrm{N}_{2}$ production $\left(61.4 \mathrm{mmol} \mathrm{N} \mathrm{m}^{-2} \mathrm{yr}^{-1}\right.$ or 168.2 $\mu \mathrm{mol} \mathrm{N} \mathrm{m}^{-2} \mathrm{~d}^{-1}$ ), while only $1 \%$ was mediated by anammox $\left(0.6 \mathrm{mmol} \mathrm{N} \mathrm{m}^{-2} \mathrm{yr}^{-1}\right.$ or $1.6 \mu \mathrm{mol} \mathrm{N} \mathrm{m} \mathrm{N}^{-2}$ $\left.\mathrm{d}^{-1}\right)$. The contribution from anammox was at the lower end of values reported for Greenland coastal sediments during spring and summer, where anammox accounted for 1 to $35 \%$ of the $\mathrm{N}_{2}$ production, with rates ranging between 1 and $92 \mu \mathrm{mol} \mathrm{N} \mathrm{m}^{-2} \mathrm{~d}^{-1}$ (Rysgaard et al. 2004). The relative contribution of anammox was also unusually low for sediments at a water depth of $100 \mathrm{~m}$ (Trimmer \& Engström 2011, Thamdrup 2012). As of yet, there is no obvious explanation for this low contribution, as factors controlling the contribution from anammox are still poorly understood. The absolute values of denitrification in the previous Arctic study ranged from 33 to $265 \mu \mathrm{mol}$ $\mathrm{N} \mathrm{m}^{-2} \mathrm{~d}^{-1}$ (Rysgaard et al. 2004), which is slightly 
lower than the spring and summer values from the present study (106-557 $\mu \mathrm{mol} \mathrm{N} \mathrm{m}{ }^{-2} \mathrm{~d}^{-1}$ ). This is most likely due to a higher availability of reactive organic material in Kobbefjord compared to most of the sites investigated by Rysgaard et al. (2004), as increased organic material availability stimulates mineralization rates (Canfield 1989) including denitrification (Jørgensen 1996). Despite these relatively high rates, the contribution from denitrification to the annual benthic carbon mineralization rate was only $2 \%$, applying the general mineralization stoichiometry of denitrification (1 $\mathrm{CO}_{2}: 0.8 \mathrm{NO}_{3}$, Fig. 7). This aligns with other coastal studies both temperate and Arctic, generally showing a contribution of 2 to $6 \%$ from denitrification to the overall carbon mineralization rate (e.g. Canfield et al. 1993, Rysgaard et al.1998, Kostka et al. 1999).

With denitrification accounting for $0.1 \pm 0.2 \mathrm{~mol} \mathrm{C}$ $\mathrm{m}^{-2} \mathrm{yr}^{-1}$ and SRR for $2.2 \pm 0.7 \mathrm{~mol} \mathrm{C} \mathrm{m}{ }^{-2} \mathrm{yr}^{-1}$, the annual carbon mineralization contribution ascribed to aerobic respiration, iron, and manganese reduction amounts to $0.9 \mathrm{~mol} \mathrm{C} \mathrm{m}{ }^{-2} \mathrm{yr}^{-1}(3.2-2.2-0.1 \mathrm{~mol} \mathrm{C}$ $\mathrm{m}^{-2} \mathrm{yr}^{-1}$, Fig. 7). In summary, the relative contributions of the different diagenetic pathways to the total carbon mineralization from this study resembles previous observations of temperate (Thamdrup 2000) and Arctic studies with similar deposition rates of organic material (e.g. Kostka et al. 1999). Altogether, our work aligns with previous studies which indicated that deposition rate and degradability of organic material, rather than low temperature, exerts the dominating control on the relative importance of the diagenetic pathways and the benthic mineralization rates (Sagemann et al. 1998, Thamdrup \& Fleischer 1998, Berg et al. 2003).

The carbon burial rate calculated from the carbon content and sediment burial rate corresponded to $5.3 \pm 1.7 \mathrm{~mol} \mathrm{C} \mathrm{m}^{-2} \mathrm{yr}^{-1}$ (Fig. 7). Hence, the estimated carbon deposition rate from the water column measurements (POC export 19.9 minus pelagic respiration $9.5=10.4 \mathrm{~mol} \mathrm{C} \mathrm{m}^{-2} \mathrm{yr}^{-1}$ ) is very similar to the estimated carbon deposition rate from benthic measurements (benthic mineralization $3.2+$ burial rate $5.3=$ $8.5 \mathrm{~mol} \mathrm{C} \mathrm{m}{ }^{-2} \mathrm{yr}^{-1}$ ). As these values were determined independently, this provides confidence in the carbon budget presented here. Overall, $\sim 31 \%$ of the organic carbon that reached the sediment was mineralized, while the remainder was sequestered in the sediment record.

Based on the bathymetry of the seabed and the size of the deposition area in Kobbefjord, the burial rates assessed for the central deposition area (the present study site) must exceed the average rates of the entire area due to sediment focusing. As the slopes in Kobbefjord consist of rocks and gravel with little net deposition, it was assumed that carbon was focused in the estimated bottom area of $8.6 \mathrm{~km}^{2}$, representing only $34 \%$ of the surface area $\left(25 \mathrm{~km}^{2}\right)$ of Kobbefjord. Therefore, scaling the carbon burial in Kobbefjord to the surface area, the annual burial of $547 \mathrm{t} \mathrm{C} \mathrm{yr}^{-1}$ (total burial for a deposition area of $8.6 \mathrm{~km}^{2}$ ) in the basin would correspond to a fjord-scale carbon sink of $22 \mathrm{t} \mathrm{C} \mathrm{km} \mathrm{km}^{-2} \mathrm{yr}^{-1}$. Previous work has suggested that biological processes are important drivers for atmospheric $\mathrm{CO}_{2}$ drawdown in Kobbefjord (Sejr et al. 2014) and Godthåbsfjord (Meire et al. 2015). Assuming a similar atmospheric $\mathrm{CO}_{2}$ drawdown in Kobbefjord as in Godhåbsfjord (65 to $86 \mathrm{t} \mathrm{C} \mathrm{km}^{-2} \mathrm{yr}^{-1}$; Rysgaard et al. 2012, Meire et al. 2015), the estimated benthic carbon burial as derived by our current study, which must represent the ultimate sink for the biological net drawdown of $\mathrm{CO}_{2}$ from the atmosphere, only corresponds to 25 to $34 \%$ of the carbon entering the system. This suggests that surface cooling and inflow and mixing of glacial melt water undersaturated in $\mathrm{CO}_{2}$ (Rysgaard et al. 2012, Sejr et al. 2014, Meire et al. 2015) are of significant importance for the observed $\mathrm{CO}_{2}$ drawdown in the region.

\section{Arctic fjords and climate change}

The impact of future climate change on high-Arctic fjords can be evaluated by taking advantage of the natural climate gradient and comparing the biogeochemical function of low- and high-Arctic fjords (Rysgaard et al. 2003). Young Sound (latitude $74^{\circ} 18.580^{\prime} \mathrm{N}$ ) is one of the few high-Arctic marine systems where the marine carbon cycle has been quantified in detail (Rysgaard \& Glud 2007). Currently, the short ice-free period of $\sim 2.5$ mo in Young Sound induces a peak in pelagic primary production and POC export following the sea-ice break-up. However, the ice-free period in Young Sound is projected to double by the end of the 21st century (Rysgaard \& Glud 2007). The prolonged ice-free period is expected to increase annual primary production and POC export, as well as the benthic mineralization and burial of organic material.

Primary production and the export of organic material in Young Sound amount to 13 and $7 \%$ of the values in Kobbefjord, respectively. Using the established depth dependency in annual benthic carbon mineralization (Glud et al. 2000, Thamdrup et al. 2007), the mineralization rate at $107 \mathrm{~m}$ in Young Sound would amount to $0.65 \mathrm{~mol} \mathrm{C} \mathrm{m}{ }^{-2} \mathrm{yr}^{-1}(20 \%$ of 
the rate in Kobbefjord) and the burial of organic carbon to $0.81 \mathrm{~mol} \mathrm{C} \mathrm{m}^{-2} \mathrm{yr}^{-1}$, or $15 \%$ of the Kobbefjord value (Thamdrup et al. 2007). Hence, primary production, benthic mineralization, and burial rates in Young Sound are 5 to 8 times lower than in Kobbefjord (Table 2).

A data compilation by Rysgaard et al. (1999) and Rysgaard \& Glud (2007) demonstrated a close relation between the ice-free period and annual primary production in the Arctic. Compiling only data from Arctic fjords indicates a similar relationship (Fig. 8A), and assuming a linear relation, we estimate that the predicted doubling of ice-free days (Rysgaard \& Glud 2007) would result in a corresponding doubling of the annual primary production. This positive relationship is also expected to apply to the net organic material deposition rates, and, as benthic mineralization and burial are predominantly controlled by the availability of organic material (Sagemann et al. 1998, Thamdrup \& Fleischer 1998, this study), a similar relationship is assumed between the duration of the ice-free period and both benthic mineralization and

Table 2. Carbon budget for Kobbefjord (KF) and Young Sound (YS), Greenland, including the relative contribution from denitrification (Den) and sulfate reduction rate (SRR) to the annual benthic carbon mineralization, and the ratios between the respective processes and transport rates fromYS and KF. POC: particulate organic carbon

\begin{tabular}{|c|c|c|c|c|c|c|c|c|c|}
\hline Study site & $\begin{array}{l}\text { Ice-free } \\
\text { period } \\
\text { (d) }\end{array}$ & $\begin{array}{l}\text { Water } \\
\text { depth } \\
(\mathrm{m})\end{array}$ & $\begin{array}{c}\text { Primary } \\
\text { production } \\
\left(\mathrm{mol} \mathrm{C} \mathrm{m}^{-2} \mathrm{yr}^{-1}\right)\end{array}$ & 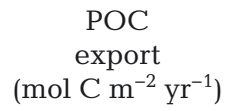 & $\begin{array}{c}\text { Pelagic } \\
\text { mineralization } \\
\left(\mathrm{mol} \mathrm{C} \mathrm{m}^{-2} \mathrm{yr}^{-1}\right)\end{array}$ & $\begin{array}{c}\text { Benthic } \\
\text { mineralization } \\
\left(\mathrm{mol} \mathrm{C} \mathrm{m}^{-2} \mathrm{yr}^{-1}\right)\end{array}$ & $\begin{array}{c}\text { Benthic } \\
\text { burial } \\
\left(\mathrm{mol} \mathrm{C} \mathrm{m} \mathrm{C}^{-2} \mathrm{yr}^{-1}\right)\end{array}$ & $\begin{array}{l}\text { Den } \\
(\%)\end{array}$ & $\begin{array}{l}\text { SRR } \\
(\%)\end{array}$ \\
\hline Kobbefjord & $\sim 300^{\mathrm{a}}$ & 107 & $7.2^{\mathrm{a}}$ & $19.9^{\mathrm{a}}$ & $9.5^{\mathrm{a}}$ & $3.2^{\mathrm{a}}$ & $5.3^{\mathrm{a}}$ & $2^{\mathrm{a}}$ & $69^{\mathrm{a}}$ \\
\hline Young Sound & $\sim 80^{\mathrm{b}}$ & 107 & $0.9^{\mathrm{c}}$ & $1.4^{\mathrm{d}}$ & $1.1^{\mathrm{e}}$ & $0.65^{\mathrm{f}}$ & $0.8^{\mathrm{g}}$ & $2^{g}$ & $57^{9}$ \\
\hline Ratio YS:KF & 4 & & 8 & 14 & 8 & 5 & 6 & - & - \\
\hline \multicolumn{10}{|c|}{${ }^{\text {apresent study }}$} \\
\hline \multicolumn{10}{|c|}{${ }^{\mathrm{b}}$ Estimated ice-free period from Rysgaard \& Glud (2007) } \\
\hline \multicolumn{10}{|c|}{${ }^{\mathrm{c} A n n u a l ~ r a t e s ~ o f ~ p r i m a r y ~ p r o d u c t i o n ~ f r o m ~ R y s g a a r d ~ e t ~ a l . ~(1999) ~}$} \\
\hline \multicolumn{10}{|c|}{ dAnnual rates of POC export from Rysgaard \& Sejr (2007) } \\
\hline \multicolumn{10}{|c|}{ eAnnual rates of pelagic mineralization from Nielsen et al. (2007) } \\
\hline \multicolumn{10}{|c|}{$\begin{array}{l}{ }^{f} \text { Rates of benthic mineralization estimated from the depth-dependent decrease in mineralization rates as shown by Glud et } \\
\text { al. (2000) and Thamdrup et al. (2007) }\end{array}$} \\
\hline \multicolumn{10}{|c|}{$\begin{array}{l}\text { gBurial rates and relative contribution from denitrification and sulfate reduction to the total annual mineralization rate from } \\
\text { Glud et al. (2000) }\end{array}$} \\
\hline
\end{tabular}
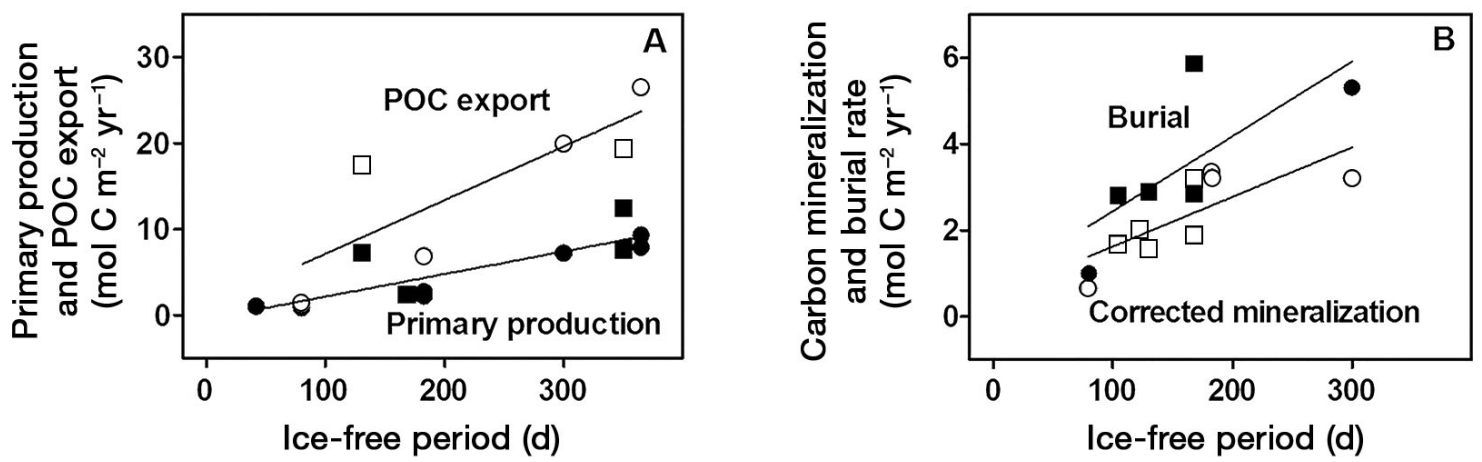

Fig. 8. (A) Primary production rates (filled symbols) and particulate organic carbon (POC) export (open symbols), and (B) benthic mineralization (open symbols) and burial rates (closed symbols) of organic carbon ( $\mathrm{mol} \mathrm{C} \mathrm{m}^{-2} \mathrm{yr}^{-1}$ ) plotted as function of the duration of the ice-free period (d) as assessed by 14 studies from fjords in Greenland and Svalbard. In both plots, the rates from Greenlandic fjords are shown as circles, while fjords from Svalbard are shown as squares. Carbon mineralization rates were adjusted according to the water depth dependence of benthic mineralization rates as presented by Glud et al. (2000) and Thamdrup et al. (2007), so that all the mineralization rates correspond to a water depth of $107 \mathrm{~m}$; the correlation is therefore termed 'corrected mineralization.' The best linear correlation between the duration of the ice-free period (days, d) and primary production, POC export, carbon mineralization, and carbon burial were given by the following equations: primary production $=0.026 \mathrm{~d}$ $-0.487\left(r^{2}=0.69\right)$, POC export $=0.062 d+0.883\left(r^{2}=0.69\right)$, mineralization $=0.011 d+0.479\left(r^{2}=0.58\right)$, and burial $=0.017 d+0.714$ $\left(r^{2}=0.55\right)$. Data for $(A)$ were extracted from: Andersen $(1977,1981)$, Eilertsen et al. (1989), Rysgaard et al. (1999), Hop et al. (2002), Levinsen \& Nielsen (2002), Leu et al. (2011), annual reports e.g. Jensen \& Rasch (2012), and the present study. Data for

(B) were extracted from: Glud et al. (1998, 2000), Rysgaard et al. (1998), Vandieken et al. (2006), and the present study 
burial (Fig. 8B). Using these relationships, the predicted increase in the ice-free period in Young Sound from $80 \mathrm{~d}$ today to $160 \mathrm{~d}$ by the end of the 21 st century (Rysgaard et al. 2003) would lead to an estimated doubling of both benthic mineralization and burial (Fig. 8B).

Increases in productivity and subsequent net deposition are expected to enhance the relative importance of anaerobic degradation pathways such as SRR (Canfield 1989), which our data support with anaerobic processes in Kobbefjord being of greater importance than in Young Sound (Table 2). To the extent that the reactive iron buffer capacity of the sediment is exceeded, this could potentially lead to periods of free $\mathrm{H}_{2} \mathrm{~S}$ accumulation in the sediment, as known for many temperate sites (Fossing et al. 2003). This could cause drastic changes in the composition and biogeochemical function of the benthic macrofauna communities. However, free $\mathrm{H}_{2} \mathrm{~S}$ was not detected at any point in the sediments of Kobbefjord, and the net deposition here (or those projected for Young Sound) does not seem to be sufficient to exceed the sediment $\mathrm{H}_{2} \mathrm{~S}$ buffering capacity. Thus, despite the predicted increase in both mineralization and burial rates, the shift in mineralization pathways is only expected to exert a minor effect on the macrofaunal community.

Acknowledgements. The study was financially supported by the Faculty of Science at the University of Southern Denmark, the Danish Council for Independent Research (FNU12-125843), The Danish Research Foundation (DNRF53), ERC Advanced Grants (ERC-2010-AdG-20100224), ERC Starting Grant 306933 (F.J.R.M.), the Commission for Scientific Research in Greenland (GCRC6507), the Canada Excellence Research Chair Program (S.R.), and the Research Foundation Flanders (FWO aspirant grant to L.M.). The study was conducted in collaboration with the marine monitoring program Marine Basic Nuuk, part of the Greenland Ecosystem Monitoring (GEM). We thank Karl Attard, Martin Blicher, Piet van Graever, Anni Glud, Anna Haxen, and Thomas Krogh for field and laboratory assistance. Additionally, we thank John Mortensen for helpful discussions on the oceanographic conditions in Kobbefjord.

\section{LITERATURE CITED}

Andersen O (1977) Primary production, illumination and hydrography in Jørgen Brønlund Fjord, North Greenland. Medd Gronl 205:1-27

Andersen O (1981) The annual cycle of phytoplankton primary production and hydrography in the Disco Bugt area, West Greenland. Medd Gronl Biosci 6:1-65

Appleby PG, Oldfield F (1992) Application of lead-210 to sedimentation studies. In: Ivanovich M, Harmon RS (eds) Uranium-series disequilibrium. Applications to earth, marine and environmental sciences. Clarendon Press, Oxford, p 731-778
Attard KM, Glud RN, McGinnis DF, Rysgaard S (2014) Seasonal rates of benthic primary production in a Greenland fjord measured by aquatic eddy correlation. Limnol Oceanogr 59:1555-1569

> Bamber J, Van Den Broeke M, Ettema J, Lenaerts J, Rignot E (2012) Recent large increases in freshwater fluxes from Greenland into the North Atlantic. Geophys Res Lett 39: L19501, doi:10.1029/2012GL052552

Bendtsen J, Mortensen J, Rysgaard S (2014) Seasonal surface layer dynamics and sensitivity to runoff in a high Arctic fjord (Young Sound/Tyrolerfjord, $74^{\circ} \mathrm{N}$ ). J Geophys Res Oceans 119:6461-6478

Berg P, Risgaard-Petersen N, Rysgaard S (1998) Interpretation of measured concentration profiles in sediment pore water. Limnol Oceanogr 43:1500-1510

Berg P, Rysgaard S, Thamdrup B (2003) Dynamic modeling of early diagenesis and nutrient cycling. A case study in an Artic marine sediment. Am J Sci 303:905-955

Bindoff NL, Willebrand J, Artale V, Cazenave A and others (2007) Observations: oceanic climate change and sea level. In: Solomon S, Qin D, Manning M, Chen Z and others (eds) Climate change 2007: the physical science basis. Contribution of Working Group I to the Fourth Assessment Report of the Intergovernmental Panel on Climate Change. Cambridge University Press, Cambridge, p 385-432

Canfield DE (1989) Sulfate reduction and oxic respiration in marine sediments: implications for organic carbon preservation in euxinic environments. Deep-Sea Res A 36:121-138

Canfield DE, Jørgensen BB, Fossing H, Glud RN and others (1993) Pathways of organic carbon oxidation in three continental margin sediments. Mar Geol 113:27-40

De Stigter HC, Jesus CC, Boer W, Richter TO, Costa A, van Weering TCE (2011) Recent sediment transport and deposition in the Lisbon-Setúbal and Cascais submarine canyons, Portuguese continental margin. Deep-Sea Res II 58:2321-2344

Eilertsen H, Taasen J, Weslawsky J (1989) Phytoplankton studies in the fjords of West Spitzbergen: physical environment and production in spring and summer. J Plankton Res 11:1245-1260

Fossing H, Berg P, Thamdrup B, Rysgaard S, Sørensen H, Nielsen K (2003) Ilt- og næringsstofflux-model for Århus Bugt og Mariager Fjord. Modelopsætning og scenarier. Faglig rapport fra DMU, no. 417. Available at: http:// www2.dmu.dk/1_viden/2_Publikationer/3_fagrapporter/ rapporter/FR417A.pdf

France RL (1995) Carbon-13 enrichment in benthic compared to planktonic algae: foodweb implications. Mar Ecol Prog Ser 124:307-312

Glud RN (2008) Oxygen dynamics of marine sediments. Mar Biol Res 4:243-289

Glud RN, Holby O, Hoffmann F, Canfield DE (1998) Benthic mineralization and exchange in Arctic sediments (Svalbard, Norway). Mar Ecol Prog Ser 173:237-251

Glud RN, Risgaard-Petersen N, Thamdrup B, Fossing $\mathrm{H}$, Rysgaard S (2000) Benthic carbon mineralization in a high-Arctic sound (Young Sound, NE Greenland). Mar Ecol Prog Ser 206:59-71

> Hop H, Pearson T, Hegseth EN, Kovacs KM and others (2002) The marine ecosystem of Kongsfjorden, Svalbard. Polar Res 21:167-208

Iversen N, Jørgensen BB (1985) Anaerobic methane oxidation rates at the sulfate-methane transition in marine 
sediments from Kattegat and Skagerrak (Denmark). Limnol Oceanogr 30:944-955

Jensen L, Rasch M (2009) NERO 3rd Annual Report 2009. National Environmental Research Institute, Aarhus University, Aarhus

Jensen L, Rasch M (2012) NERO 6th Annual Report 2012. National Environmental Research Institute, Aarhus University, Aarhus

Jørgensen BB (1978) A comparison of methods for the quantification of bacterial sulfate reduction in coastal marine sediments 1. Measurement with radiotracer techniques. Geomicrobiol J 1:11-27

Jørgensen BB (1996) Case study: Århus Bay. In: Jørgensen $\mathrm{BB}$, Richardson K (eds) Eutrophication in coastal marine ecosystems. Coastal and estuarine studies no. 52. American Geophysical Union, Washington, DC, p 137-154

> Juul-Pedersen T, Nielsen TG, Michel C, Møller EF and others (2006) Sedimentation following the spring bloom in Disko Bay, West Greenland, with special emphasis on the role of copepods. Mar Ecol Prog Ser 314:239-255

Juul-Pedersen T, Arendt KE, Mortensen J, Blicher ME, Søgaard DH, Rysgaard S (2015) Seasonal and interannual phytoplankton production in a sub-Arctic tidewater outlet glacier fjord, SW Greenland. Mar Ecol Prog Ser 524:27-38

Kallmeyer J, Ferdelman T, Weber A, Fossing H, Jørgensen BB (2004) A cold chromium distillation procedure for radiolabeled sulfide applied to sulfate reduction measurements. Limnol Oceanogr Methods 2:171-180

Kostka JE, Thamdrup B, Glud RN, Canfield DE (1999) Rates and pathways of carbon oxidation in permanently cold Arctic sediments. Mar Ecol Prog Ser 180:7-21

Krause-Jensen D, Marbà N, Olesen B, Sejr MK and others (2012) Seasonal sea ice cover as principal driver of spatial and temporal variation in depth extension and annual production of kelp in Greenland. Glob Change Biol 18:2981-2994

> Leu E, Søreide JE, Hessen DO, Falk-Petersen S, Berge J (2011) Consequences of changing sea-ice cover for primary and secondary producers in the European Arctic shelf seas: timing, quantity, and quality. Prog Oceanogr 90:18-32

> Levinsen H, Nielsen TG (2002) The trophic role of marine pelagic ciliates and heterotrophic dinoflagellates in arctic and temperate coastal ecosystems: a cross-latitude comparison. Limnol Oceanogr 47:427-439

Li YH, Gregory S (1974) Diffusion of ions in sea water and in deep-sea sediments. Geochimica Cosmochim Acta 38: 703-714

Meire L, Søgaard DH, Mortensen J, Meysman FJR and others (2015) Glacial meltwater and primary production are drivers of strong $\mathrm{CO}_{2}$ uptake in fjord and coastal waters adjacent to the Greenland Ice Sheet. Biogeosciences 12: 2347-2363

Middelboe M, Glud RN, Sejr MK (2012) Bacterial carbon cycling in a subarctic fjord: a seasonal study on microbial activity, growth efficiency, and virus-induced mortality in Kobbefjord, Greenland. Limnol Oceanogr 57: 1732-1742

Mikkelsen DM, Rysgaard S, Glud RN (2008) Microalgal composition and primary production in Arctic sea ice: a seasonal study from Kobbefjord (Kangerluarsunnguaq), West Greenland. Mar Ecol Prog Ser 368:65-74

Mortensen J, Lennert K, Bendtsen J, Rysgaard S (2011) Heat sources for glacial melt in a sub-Arctic fjord (Godthåbs- fjord) in contact with the Greenland Ice Sheet. J Geophys Res 116:1-13

Nielsen L (1992) Denitrification in sediment determined from nitrogen isotope pairing. FEMS Microbiol Ecol 86: 357-362

Nielsen TG, Ottosen LD, Hansen BW (2007) Structure and function of the pelagic ecosystem in Young Sound, NE Greenland. In: Rysgaard S, Glud RN (eds) Carbon cycling in Arctic marine ecosystems: case study Young Sound. Meddelser om Grønland. Bioscience. Vol 58. Danish Polar Center, Copenhagen, p 86-107

- Nittrouer CA, DeMaster DJ, Mckee BA, Cutshall NH (1984) The effect of sediment mixing on $210 \mathrm{~Pb}$ accumulation rates for the Washington continental shelf. Mar Geol 54: 201-221

Rasmussen H, Jørgensen BB (1992) Microelectrode studies of seasonal oxygen uptake in a coastal sediment: role of molecular diffusion. Mar Ecol Prog Ser 81:289-303

Revsbech NP (1989) An oxygen microsensor with a guard cathode. Limnol Oceanogr 34:474-478

Risgaard-Petersen N, Nielsen L, Rysgaard S, Dalsgaard T, Meyer R (2003) Application of the isotope pairing technique in sediments where anammox and denitrification coexist. Limnol Oceanogr Methods 1:61-71

Rysgaard S, Glud RN (2007) Carbon cycling and climate changes: predictions for a high-Arctic marine ecosystem (Young Sound, NE Greenland). In: Rysgaard S, Glud RN (eds) Carbon cycling in Arctic marine ecosystems: case study Young Sound. Meddelser om Grønland. Bioscience. Vol 58. Danish Polar Center, Copenhagen, p 204-214

Rysgaard S, Sejr M (2007) Vertical flux of particulate organic matter in a high Arctic fjord: relative inportance of terrestrial and marine sources. In: Rysgaard S, Glud RN (eds) Carbon cycling in Arctic marine ecosystems: case study Young Sound. Meddelser om Grønland. Bioscience. Vol 58. Danish Polar Center, Copenhagen, p 108-119

> Rysgaard S, Thamdrup B, Risgaard-Petersen N, Fossing H, Berg P, Bondo Christensen P, Dalsgaard T (1998) Seasonal carbon and nutrient mineralization in a high-Arctic coastal marine sediment, Young Sound, Northeast Greenland. Mar Ecol Prog Ser 175:261-276

- Rysgaard S, Nielsen TG, Hansen BW (1999) Seasonal variation in nutrients, pelagic primary production and grazing in a high-Arctic coastal marine ecosystem, Young Sound, Northeast Greenland. Mar Ecol Prog Ser 179:13-25

> Rysgaard S, Vang T, Stjernholm M, Rasmussen B, Windelin A, Kiilsholm S (2003) Physical conditions, carbon transport, and climate change impacts in a Northeast Greenland Fjord. Arct Antarct Alp Res 35:301-312

Rysgaard S, Glud RN, Risgaard-Petersen N, Dalsgaard T (2004) Denitrification and anammox activity in Arctic marine sediments. Limnol Oceanogr 49:1493-1502

> Rysgaard S, Mortensen J, Juul-Pedersen T, Sørensen LL and others (2012) High air-sea $\mathrm{CO}_{2}$ uptake rates in nearshore and shelf areas of Southern Greenland: temporal and spatial variability. Mar Chem 128-129:26-33

Sagemann J, Jørgensen BB, Greeff O (1998) Temperature dependence and rates of sulfate reduction in cold sediments of Svalbard, Arctic Ocean. Geomicrobiol J 15: 85-100

Sejr MK, Nielsen TG, Rysgaard S, Risgaard-Petersen N, Sturluson M, Blicher ME (2007) Fate of pelagic organic carbon and importance of pelagic-benthic coupling in a shallow cove in Disko Bay, West Greenland. Mar Ecol Prog Ser 341:75-88 
Sejr MK, Krause-Jensen D, Dalsgaard T, Ruiz-Halpern S and others (2014) Seasonal dynamics of autotrophic and heterotrophic plankton metabolism and $\mathrm{PCO}_{2}$ in a subarctic Greenland fjord. Limnol Oceanogr 59:1764-1778

Simpson JH (1981) The shelf-sea fronts: implications of their existence and behaviour. Philos Trans R Soc Lond B Biol Sci 302:531-546

Steeman Nielsen E (1952) The use of radioactive carbon $\left(\mathrm{C}^{14}\right)$ for measuring organic production in the sea. J Cons Int Explor Mer 18:117-140

Stendel M, Christensen JH, Aðalgeirsdóttir G, Klien N, Drews M (2007) Regional climate change for Greenland and surrounding seas. Part I: atmosphere and land surface. Danish Meterological Institute, Copenhagen

Thamdrup B (2000) Bacterial manganese and iron reduction. In: Schink B (ed) Advances in microbial ecology, 16. Kluwer Academic, New York, NY, p 44-84

Thamdrup B (2012) New pathways and processes in the global nitrogen cycle. Annu Rev Ecol Evol Syst 43: 407-428

Thamdrup B, Fleischer S (1998) Temperature dependence of oxygen respiration, nitrogen mineralization, and nitrification in Arctic sediments. Aquat Microb Ecol 15:191-199

Thamdrup B, Glud RN, Hansen J (2007) Benthic carbon cycling in Young Sound, Northeast Greenland. In: Rys-

Editorial responsibility: William Kemp,

Cambridge, Maryland, USA gaard S, Glud RN (eds) Carbon cycling in Arctic marine ecosystems: case study Young Sound. Meddelser om Grønland. Bioscience. Vol 58. Danish Polar Center, Copenhagen, p 136-157

Therkildsen M, Lomstein B (1993) Seasonal variation in net benthic $\mathrm{C}$-mineralization in a shallow estuary. FEMS Microbiol Ecol 12:131-142

Trimmer M, Engström P (2011) Distribution, activity, and ecology of anammox bacteria in aquatic environments. In: Ward B, Arp D, Klotz M (eds) Nitrification. ASM Press, Washington, DC, p 201-235

Vandieken V, Finke N, Jørgensen BB (2006) Pathways of carbon oxidation in an Arctic fjord sediment (Svalbard) and isolation of psychrophilic and psychrotolerant Fe (III)-reducing bacteria. Mar Ecol Prog Ser 322:29-41

Vaughan DG, Comiso JC, Allison I, Carrasco J and others (2013) Observations: cryosphere. In: Stocker TF, Qin D, Plattner GK, Tignor M and others (eds) Climate change 2013: the physical science basis. Contribution of Working Group I to the 5th Assessment Report of the Intergovernmental Panel on Climate Change. Cambridge University Press, Cambridge

Wassmann P (1984) Sedimentation and benthic mineralization of organic detritus in a Norwegian fjord. Mar Biol 83: 83-94

Submitted: May 6, 2015; Accepted: September 28, 2015 Proofs received from author(s): November 2, 2015 